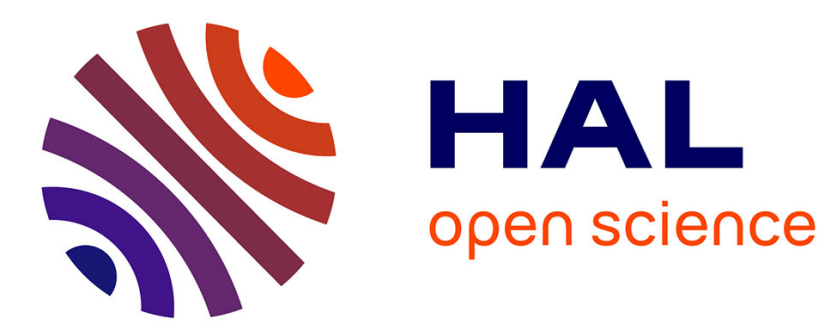

\title{
Urea based foldamers
}

Sung Hyun Yoo, Bo Li, Christel Dolain, Morgane Pasco, Gilles Guichard

\section{To cite this version:}

Sung Hyun Yoo, Bo Li, Christel Dolain, Morgane Pasco, Gilles Guichard. Urea based foldamers. E. James Petersson. Synthetic and Enzymatic Modifications of the Peptide Backbone, 656, Elsevier, pp.59-92, 2021, Methods in Enzymology, 10.1016/bs.mie.2021.04.019 . hal-03428128

\section{HAL Id: hal-03428128 \\ https://hal.science/hal-03428128}

Submitted on 15 Nov 2021

HAL is a multi-disciplinary open access archive for the deposit and dissemination of scientific research documents, whether they are published or not. The documents may come from teaching and research institutions in France or abroad, or from public or private research centers.
L'archive ouverte pluridisciplinaire HAL, est destinée au dépôt et à la diffusion de documents scientifiques de niveau recherche, publiés ou non, émanant des établissements d'enseignement et de recherche français ou étrangers, des laboratoires publics ou privés. 
2 Sung Hyun Yoo, Bo Li, Christel Dolain, Morgane Pasco, Gilles Guichard

3

Univ. Bordeaux, CNRS, Bordeaux INP, CBMN, UMR 5248, Institut Européen de Chimie et Biologie, 2 rue Robert Escarpit, F-33607, Pessac, France

\section{ABSTRACT}

$N, N^{\prime}$-linked oligoureas are a class of enantiopure, sequence-defined peptidomimetic oligomers without amino acids that form well-defined and predictable helical structures akin to the peptide $\alpha$ helix. Oligourea based foldamers combine a number of features - such as synthetic accessibility, sequence modularity, and folding fidelity - that bode well for their use in a range of applications from medicinal chemistry to catalysis. Moreover, it was recently recognized that this synthetic helical backbone can be combined with regular peptides to generate helically folded peptide-oligourea hybrids that display additional features in terms of helix mimicry and protein-surface recognition properties. Here we provide detailed protocols for the preparation of requested monomers and for the synthesis and purification of homo oligoureas and peptide-oligourea hybrids.

\section{CONTENTS}

1. Introduction

2. Helical structures of $N, N^{\prime}$-linked oligoureas and oligourea/peptide chimeras

3. Applications of urea-based foldamers

3.1 Cationic amphiphilic foldamers as host-defense peptide mimics and for the delivery of nucleic acids

3.2 Nanostructures by self-assembly of amphiphilic water soluble oligoureas

3.3 Chimeric helices as inhibitors of protein-protein interactions and as receptor ligands 
3.4 Composite proteins containing foldamer segments

3.5 Anion recognition, organocatalysis and electron transfer

4. Main strategies to synthesize oligourea based foldamers

4.1 Synthesis of oligoureas in solution

4.2 Fragment condensation

4.3 Solid phase synthesis of oligoureas

5. Synthetic protocols

5.1 Materials

\subsubsection{Reagents}

5.1.2 Equipment

5.2 Monomer preparation

5.2.1 Azide type monomers bearing the side chain at the ${ }^{\beta} \mathrm{C}$ position $\left(\mathrm{N}_{3}-\mathrm{Xaa}{ }^{\mathrm{u}}-\mathrm{OSu}\right)$

5.2.2 Azide type monomers bearing the side chain at the ${ }^{\alpha} \mathrm{C}$ position $\left(\mathrm{N}_{3}-\mathrm{Xaa}{ }^{\mathrm{u \alpha}}-\mathrm{OSu}\right)$

5.3 Synthesis of oligourea based foldamers on solid support

5.3.1 Solid phase synthesis of oligoureas

5.3.2 Solid phase synthesis of hybrid peptide-oligourea (PUH) or oligourea-peptide (UPH) sequences

\subsubsection{Purification and characterization of oligourea-based foldamers}

\subsubsection{Troubleshooting}

6. Concluding remarks and future directions

\section{KEYWORDS}

Foldamers, Oligourea, Peptide mimicry, Helix, Protein surface recognition, Protein-protein interactions, Chimeric peptide/oligourea helices, Solid-phase synthesis 
Advances in foldamer research have led to the discovery of a wide range of non-natural synthetic oligomers predisposed to adopt well-defined folded structures akin to those found in proteins and nucleic acids(Gellman, 1998; Goodman, Choi, Shandler, \& DeGrado, 2007; Gilles Guichard \& Huc, 2011; Horne \& Grossmann, 2020; Johnson \& Gellman, 2013; Seebach, Beck, \& Bierbaum, 2004). These synthetic sequence-specific backbones inspired by biopolymers obey different folding and selfassembly rules and provide enticing opportunities to explore entirely new chemical spaces. Although the creation of synthetic folded architectures was initially largely driven by curiosity, with a focus on exploration and conformational analysis of new backbones, it quickly turned out that the ability to synthesize sequence-based oligomers that fold with high fidelity raised the possibility of creating molecules with defined functions. In particular, it has been shown that biopolymer mimicry with foldamers can provide unique tools to study biology and may lead to the elaboration of novel diagnostic/therapeutic agents (Azzarito, Long, Murphy, \& Wilson, 2013; Checco \& Gellman, 2016; Gopalakrishnan, Frolov, Knerr, Drury, \& Valeur, 2016; Johnson \& Gellman, 2013; Pasco, Dolain, \& Guichard, 2017). For example, $\alpha / \beta$-peptides which are faithful $\alpha$-helix mimics have been developed as inhibitors of protein-protein interactions or as receptor ligands with improved pharmacological properties, increased resistance to proteolytic degradation and in some cases prolonged duration of action in vivo(Boersma et al., 2011; Checco et al., 2015; Cheloha, Maeda, Dean, Gardella, \& Gellman, 2014; Horne et al., 2009; Johnson et al., 2014; Johnson \& Gellman, 2013; Kritzer, Hodsdon, \& Schepartz, 2005; Kritzer, Stephens, Guarracino, Reznik, \& Schepartz, 2005; Lee et al., 2009; Liu, Cheloha, Watanabe, Gardella, \& Gellman, 2018; Liu et al., 2019; Michel, Harker, Tirado-Rives, Jorgensen, \& Schepartz, 2009). Furthermore, the ability to link sequence and folding within nonbiological synthetic foldamers can be exploited to create architectures reaching the size and complexity of small proteins (tertiary and quaternary structures) (Horne \& Grossmann, 2020; Pappas et al., 2020) or molecular strands that display molecular recognition properties and functions beyond those found in nature(Ferrand \& Huc, 2018; Gan et al., 2017). 


$$
\alpha \text {-peptide }
$$<smiles>[R]C(NC)C(=O)CC</smiles>

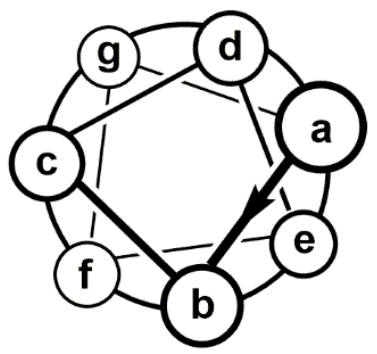

$\boldsymbol{N}, \boldsymbol{N}$-linked urea oligomer<smiles>[R][C@@H](CNC(=O)C(C)C)NC</smiles>

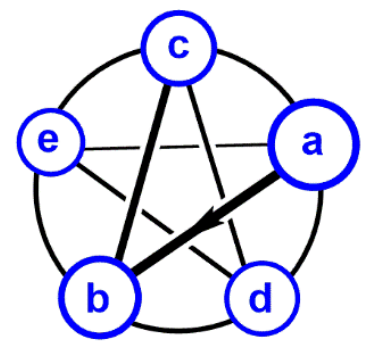

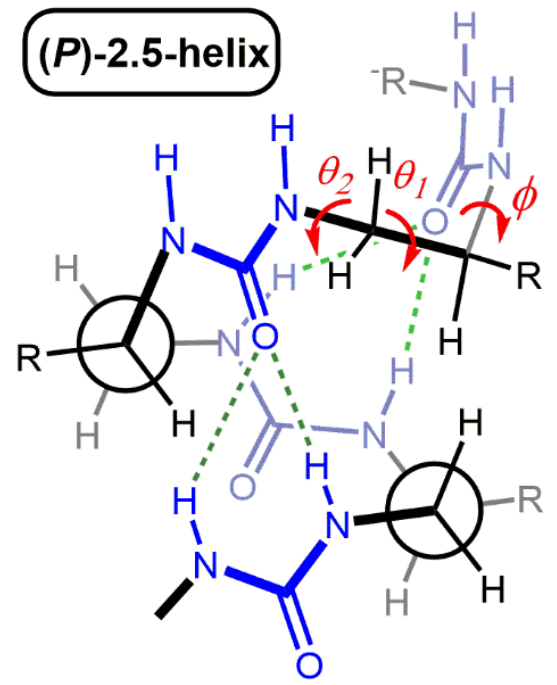

Fig. 1. Comparison of $\alpha$-peptide $(\mathrm{Xaa})_{n}$ and $N, N^{\prime}$-linked oligourea $\left(\mathrm{Xaa}{ }^{4}\right)_{n}$ backbones and representation of the 2.5-helical conformation of oligoureas showing the three center $\mathrm{H}$-bond network. Ureido residues are denoted $\mathrm{Xaa}^{\mathrm{u}}\left(\mathrm{X}^{\mathrm{u}}\right)$ by analogy to the three (one) letter code of $\alpha$-amino acids 
The helicity of urea oligomers is largely unaffected by the nature of the side chains in the sequence (in contrast to $\alpha$-peptides), which makes these foldamers robust and tunable, allowing the different side chains (including polar ones) to be faithfully displayed at the helix surface. The chemical accessibility of the chiral ethylene diamine based monomers permits the synthesis of urea oligomers that bear, yet are not limited to, any of the 20 naturally occurring amino-acid side chains. Over the years, we and others have continuously expanded the repertoire of monomers(Douat-Casassus, Pulka, Claudon, \& Guichard, 2012; Legrand et al., 2012; Y.-R. Nelli et al., 2012; Pendem, Douat, et al., 2013; Wechsel, Raftery, Cavagnat, Guichard, \& Clayden, 2016) and improved oligomer synthesis by generalizing solution(Fremaux, Fischer, Arbogast, Kauffmann, \& Guichard, 2011) and solid-phase methods(Burgess et al., 1995; Douat-Casassus et al., 2012; Gilles Guichard, Semetey, Rodriguez, \& Briand, 2000; Kim, Bi, Paikoff, \& Schultz, 1996) (see section 4 "Main strategies to synthesize oligourea based foldamers").

Thorough exploration of the requirements for secondary structure formation has shown how variation of substitution patterns (e.g. $\mathrm{N}$-pyrrolidine units (proline analogue)(Fremaux et al., 2011; Fremaux, Kauffmann, \& Guichard, 2014), constrained cis-cyclohexyl diamine units(Pendem, Nelli, et al., 2013; Wechsel et al., 2016) and even bulkier 1,2-diaminobicyclo[2.2.2]octane bicyclic units(Legrand et al., 2012; Milbeo et al., 2020)), shifted side chain from ${ }^{\beta} C$ to ${ }^{\alpha} C$ with inversion of stereochemistry; Fig. 2AC)(Pendem, Nelli, et al., 2013) and isosteric backbone modifications (e.g. insertion of $y$-amino acid residues, carbamate or thiourea linkages; Fig. 2D-G)(Y. R. Nelli et al., 2015; Y. R. Nelli, Fischer, Collie, Kauffmann, \& Guichard, 2013; Pendem, Nelli, et al., 2013) can be used to modulate helix properties and generate different spacing and orientation of side chains at the surface. 
A
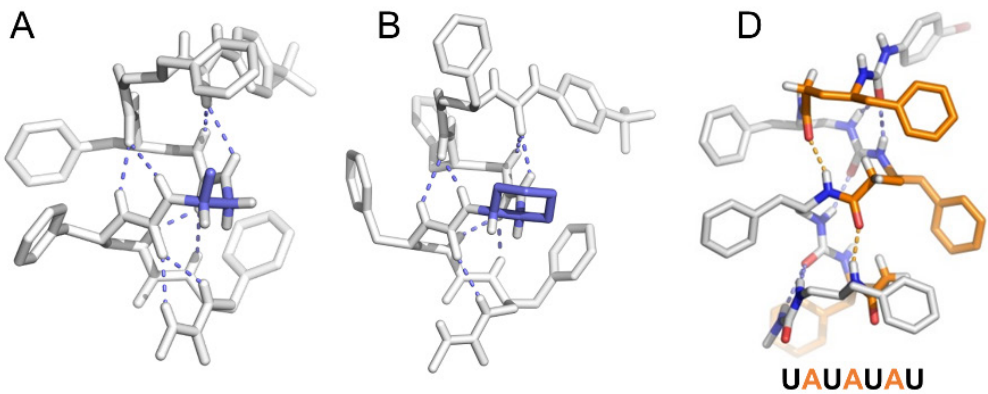

C

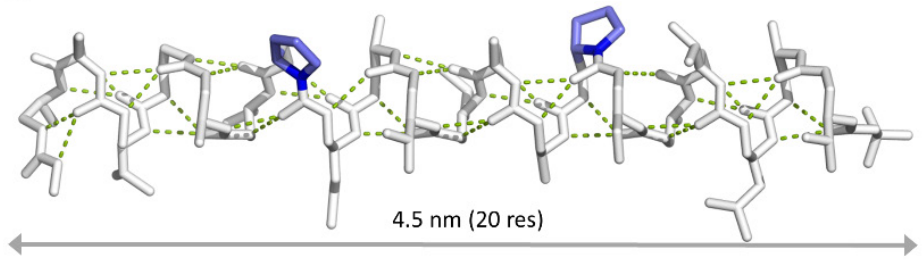

E

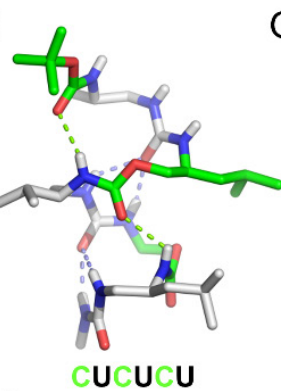

G

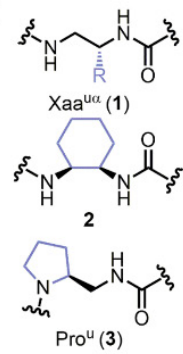

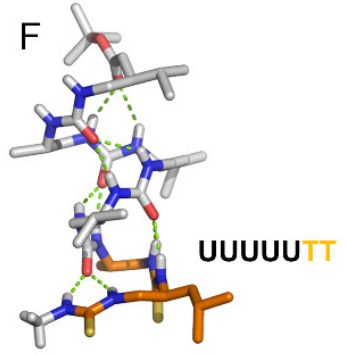

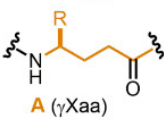

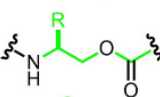

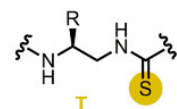

115

Fig. 2. Crystal structures of a pentaurea with a (A) shifted substitution pattern and a (B) constrained cyclohexyl ring at central residue;(Pendem, Douat, et al., 2013), (C) crystal structure of a 20-mer oligourea with two pyrrolidine units forming a long (45 ̊̊) helical segment;(Fremaux et al., 2011); crystal structures of heterogeneous backbones consisting of (D) alternating urea/amide units, (E) alternating urea/carbamate units(Pendem, Nelli, et al., 2013) and (F) mixed urea/thiourea linkages.(Y. R. Nelli et al., 2015); (G) Example of monomers with non-canonical substitution patterns (Xaa ${ }^{\mathrm{u \alpha}}(\mathbf{1})$ ciscyclohexyl (2), Pro ${ }^{4}(\mathbf{3})$ and urea isosteric units ( $\gamma$-amino acid ( $\gamma$ Xaa) A, carbamate $\mathbf{C}$ and thiourea $\mathbf{T}$ linkages) compatible with helix formation.

The similarities in screw sense, pitch and polarity between peptide $\alpha$-helices and oligourea 2.5 -helices also suggested to us that these two backbones could be combined, thus permitting key beneficial features of both species-such as natural epitope recognition of $\alpha$-peptides and the innate helical stability of oligoureas-to be exploited in single chimeric constructs. We first investigated model chimeric $\alpha$-peptide/oligourea and oligourea/ $\alpha$-peptide sequences to define the rules that govern helix formation in these sequences. The resulting chimeras (i.e. "block cofoldamers") with aliphatic oligoureas fused to short peptide segments (either at the $\mathrm{N}$ - or C-terminus or at both termini) were found to adopt a continuous helical structure in the solid state as well as in polar organic solvents, the peptide and oligourea helices being connected by a unique H-bond network(Fremaux et al., 2015; Mauran, Kauffmann, Odaert, \& Guichard, 2016). The finding that oligourea foldamers can be interfaced with natural peptide helices and that the two helical forms do communicate within a single strand is 
of particular significance for applications of foldamers in biology. Possible benefits of generating such chimeric helices include improved nucleation of $\alpha$-helical peptide segments, increased resistance to proteolysis and prolonged activities in vivo.

\section{APPLICATIONS OF UREA-BASED FOLDAMERS}

The ability to synthesize diverse, sequence-specific oligoureas that fold with a high degree of predictability has stimulated the interest of our group and others to endow urea-based foldamers with function. Examples of applications reported for urea-based foldamers range from bioactive peptide mimics(Fremaux, Venin, Mauran, Zimmer, Guichard, et al., 2019) including modulators of proteinprotein interactions(Cussol et al., 2021) to quaternary structures(Collie et al., 2015) and from electron transfer(Pulka-Ziach \& Sęk, 2017) to catalysis(Bécart et al., 2017). Some of these applications are discussed in more detail below.

3.1 Cationic amphiphilic foldamers as host-defense peptide mimics and for the delivery of nucleic acids

Short chain oligoureas designed to mimic globally amphiphilic cationic $\alpha$-helical host-defense peptides have been found to be active against a range of Gram-negative and Gram-positive bacteria(Claudon et al., 2010; Aude Violette et al., 2006). These oligoureas which display a high helical content in the vicinity of phospholipid membranes are thought to be active by a mechanism involving permeabilization of the bacterial membrane. One such foldamer was found to be active against bacterial forms of Bacillus anthracis encountered in vivo (i.e., germinating spores, encapsulated and non-encapsulated bacilli) and to exert partial protection in cutaneous and inhalational models of infection with $B$. anthracis(Teyssières et al., 2016).

Sequence variations such as $\mathrm{pH}$-responsive side chains and dimerization were introduced to convert these antimicrobial foldamers into gene transfection agents. Bioreducible helical cell penetrating foldamers (CPFs) with high capacity to assemble with plasmid DNA and to deliver nucleic acids into the 
cell were finally obtained by thiol-mediated dimerization of a short (8-mer) amphipathic helical oligourea bearing His and Arg side chains. The best compound in this series was found to compare favorably in terms of transfection efficiency with LAH4, a His-rich peptide CPP with high transfection ability(Douat et al., 2015). New CPF sequences with activity in culture medium containing up to $50 \%$ of serum as well as sequences for siRNA delivery were reported recently(Bornerie, Brion, Guichard, Kichler, \& Douat, 2021; Douat, Bornerie, Antunes, Guichard, \& Kichler, 2019).

\subsection{Nanostructures by self-assembly of amphiphilic water soluble oligoureas}

A recent extension of this early work is the design of amphiphilic water-soluble foldamer sequences for the precise construction of nanometer scale assemblies mimicking protein quaternary structures(Gavin William Collie, Karolina Pulka-Ziach, \& Gilles Guichard, 2016; Collie et al., 2015; Caterina M. Lombardo et al., 2016; Yoo, Collie, Mauran, \& Guichard, 2020). We have shown that it is possible to orient the assembly process towards compact (bundles) or extended nanostructures (fibrils, nanotubes) in aqueous conditions by sequence manipulation and redistribution of charged side chains (Fig. 3B). Importantly, we found that compact nanostructures obtained by the assembly of designed amphiphilic oligourea helices possess isolated internal cavities large enough to host guest molecules(Collie et al., 2017).

\subsection{Chimeric helices as inhibitors of protein-protein interactions and as receptor ligands}

The structural similarity between oligourea and peptide helices suggests that the introduction of oligourea inserts into bioactive peptides could be used to generate effective inhibitors of proteinprotein interactions or receptor ligands with a reduced peptide character (Fig. 3C). However, one difficulty associated with the use of foldamers as $\alpha$-helix mimics is to select and arrange key side chains on the surface of the foldamer so as to maintain key contacts with the target. By selecting ubiquitin ligase MDM2, vitamin D receptor and histone chaperon ASF1 as targets, we have designed peptide/oligourea chimeras that retain affinity for their protein target while showing increased resistance to proteolysis(Cussol et al., 2021; Mbianda et al., 2020). X-ray structure analysis of several 
of these peptide-oligourea hybrids bound to their respective protein targets confirms the high degree of $\alpha$-helix mimicry that can be achieved with oligoureas and reveals general principles that should enable the design of more potent peptide-based inhibitors of protein-protein interactions.

Peptide-oligourea chimeras have also been used to generate mimics of Class-B GPCR ligands with increased resistance to proteolytic degradation. In particular, we have shown that oligourea foldamers are effective tools to improve the pharmaceutical properties of GLP-1, a 31-amino acid peptide hormone involved in metabolism and glycemic control. Our strategy consisted in replacing four consecutive amino acids of GLP-1 by three consecutive ureido residues by capitalizing on the structural resemblance of oligourea and $\alpha$-peptide helices. The efficacy of the approach was demonstrated with three GLP-1-oligourea hybrids showing prolonged activity in vivo(Fremaux, Venin, Mauran, Zimmer, Guichard, et al., 2019). We have also shown that modified GLP-1 analogues with a single ureido residue replacement at position 2 exhibit antidiabetic properties and longer duration of action via selective enhancement of G protein-dependent cAMP signaling and altered GLP-1R trafficking(Fremaux, Venin, Mauran, Zimmer, Koensgen, et al., 2019).

\subsection{Composite proteins containing foldamer segments}

Encouraged by the similarity between peptide and oligourea helices, we have explored the chemical synthesis, folding, and function of composite proteins created by substituting one $\alpha$-helical regions of a target protein by non-peptide helical segments (urea-based foldamers; Fig. 3D). Such composite proteins may prove useful to interrogate protein folding, address the role of individual folded segments and modulate protein function and properties. We moved a step towards the creation of such composite proteins by replacing the 10-residue long original $\alpha$-helical segment in the Cys 2 His 2 zinc finger 3 of transcription factor Egr1 (also known as Zif268) by an oligourea sequence bearing two appropriately spaced imidazole side chains for zinc coordination(C. M. Lombardo et al., 2019). Cys2His2 zinc fingers are recurrent protein motifs involved in specific duplex DNA recognition of about 30 residues, which consist of two antiparallel strands of $\beta$-sheet connected by a turn, packed against 
an $\alpha$-helix(Wolfe, Nekludova, \& Pabo, 2000). This archetypal $\beta \beta \alpha$ fold is stabilized by a single zinc ion coordinated by a pair of cysteine residues located in the $\beta$-sheet and a pair of histidine residues located at the C-terminus of the $\alpha$-helix in a tetrahedral geometry. We have shown by spectroscopic techniques and mass spectrometry analysis under native conditions that the ability of the peptide/oligourea hybrid to coordinate zinc ion was not affected by the introduction of the foldamer insert. Moreover, detailed NMR analysis provided evidence that the engineered zinc finger motif adopts a folded structure in which the native $\beta$-sheet arrangement of the peptide region and global arrangement of DNA binding side chains are preserved. Titration in the presence of Egr1 target DNA sequence also supported binding to GC bases as reported for the wild type motif.

\subsection{Anion recognition, organocatalysis and electron transfer}

Oligoureas typically mediate interactions through their side chains but the main chain ureas also display interesting molecular recognition properties. We have shown that the helical oligourea backbone is well preorganized to bind small guest molecules such as anions. ${ }^{1} \mathrm{H}$ NMR studies in various organic solvents including DMSO revealed that anions such as carboxylate bind the positive end of the helix macrodipole without causing helix unfolding(Diemer, Fischer, Kauffmann, \& Guichard, 2016). This property was exploited to induce screw-sense preference of achiral oligourea helices consisting of meso-cyclohexane-1,2-diamine monomers by selective formation of a 1:1 hydrogen-bonded complex with a chiral carboxylate anion(Wechsel et al., 2016; Wechsel, Žabka, Ward, \& Clayden, 2018).

Taking inspiration from these studies, we envisioned that helical oligo(thio)urea foldamers could be designed to catalyze enantioselective $\mathrm{C}-\mathrm{C}$ bond formation. The catalytic system we designed is composed of two modules, including an oligourea hexamer as the $\mathrm{H}$-bonding chiral component (Fig. 3E) and a tertiary amine as a base component. We have shown that this system promotes the Michael reaction between enolizable carbonyl compounds and nitroolefins at remarkably low chiral catalyst loading with high enantioselectivity(Bécart et al., 2017). Structure-activity relationship studies revealed a strong correlation between the oligomer catalyst efficiency and its folding propensity. This 

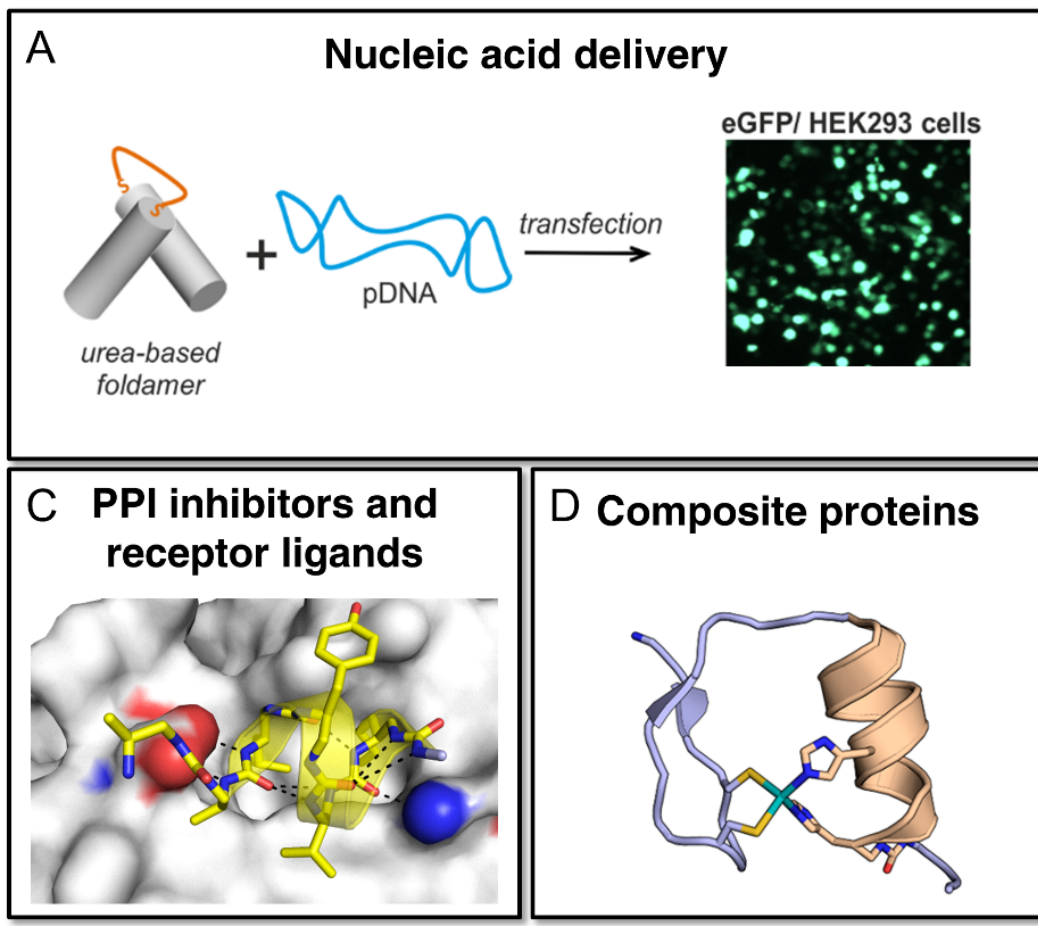

\section{B Nanostructures}
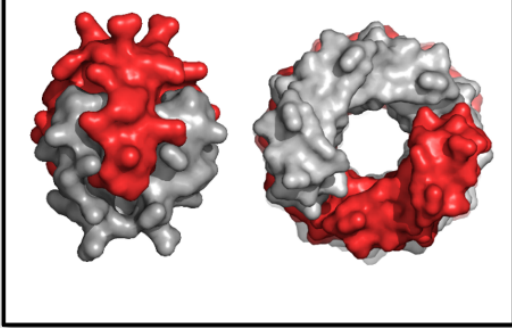

E Organocatalyst

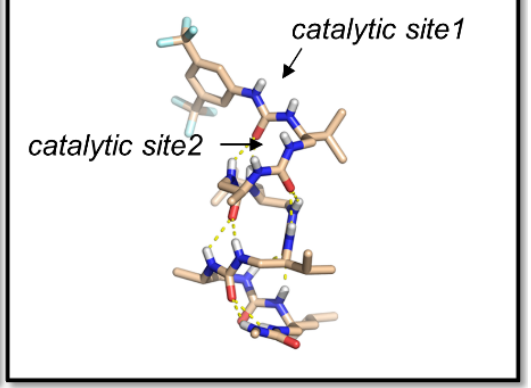

238

Fig. 3. Some Applications of urea-based foldamers. (A) $\mathrm{pH}$-responsive dimeric urea-based foldamers to enhance cellular uptake of nucleic acids. (B) X-ray structures of a hexameric bundle (left) and a helical nanotube (right) formed by self-assembly of designed amphiphilic oligourea helices. (C) X-ray structure of a short oligourea helix (yellow) mimicking key residues of the steroid receptor coactivator SRC2-3 in complex with the vitamin $D$ receptor. (D) NMR-derived low energy structure of a composite zinc finger containing a nonpeptide foldamer helical domain (peptide in light blue and oligourea in salmon). (E) Atomic structure of a hydrogen bonding oligourea-based chiral catalyst. Sources : (A) Reprinted with permission from . Copyright 2015 John Wiley \& Sons Inc. (B) : Reprinted with permission from . Copyright 2015 Springer Nature. (C) Reprinted with permission from . Copyright 2021 John Wiley \& Sons Inc. (D) Reprinted with permission from . Copyright 2019 American Chemical Society. (E) Reprinted with permission from . Copyright 2017 American Chemical Society.

\section{MAIN STRATEGIES TO SYNTHESIZE OLIGOUREA BASED FOLDAMERS}

Both solution and solid phase methods have been developed to synthesize enantiopure aliphatic $N, N^{\prime}-$

linked oligoureas. They are based on a sequential coupling of monoprotected chiral 1,2-diamine monomers activated as $O$-succinimidyl carbamates. With six positions for substituents (compare 1, 2 and $\mathbf{3}$ in Fig. 2), these building blocks are incredibly diverse (for comparison $\alpha$-amino acids contain three positions for substituents whereas $\beta$-amino acids have five). Monomers substituted at either the 

the 20 naturally occurring amino-acid side chains (Fig. 4).<smiles>[R]C(CNC(=O)ON1C(=O)CCC1=O)NP</smiles>

PGHN-Xaau-OSu<smiles>[R]C(N)CNC(=O)ON1C(=O)CCC1=O</smiles>

$\mathrm{N}_{3}-\mathrm{Xaa}^{\mathrm{u}}-\mathrm{OSu}$<smiles>[R]C(CN)NC(=O)ON1C(=O)CCC1=O</smiles>

$\mathrm{N}_{3}-\mathrm{Xaa}^{\mathrm{u \alpha}}-\mathrm{OSu}$

Fig. 4. Chemical structures of monoprotected chiral 1,2-diamine monomer and azide-type monomers, activated as $O$-succinimidyl carbamates. Ureido residues are denoted $\mathrm{Xaa}^{\mathrm{u}}$ by analogy to the threeletter code of $\alpha$-amino acids, and Xaa ${ }^{\mathrm{u} \alpha}$ related to shifted side chain from ${ }^{\beta} \mathrm{C}$ to ${ }^{\alpha} \mathrm{C}$.

\subsection{Synthesis of oligoureas in solution}

The synthesis of short oligourea sequences can be efficiently performed in solution using Bocprotected monomers by iterative coupling and deprotection steps(G. Guichard et al., 1999). The reaction of the activated carbamate with a primary or secondary amine proceeds rapidly in presence of Hünig's base at room temperature, and the only by-product formed - i.e. $N$-hydroxysuccinimide, is easily removed by aqueous workup. A short purification by flash chromatography or recrystallization affords the pure ureido derivative in good yields. The Boc-deprotection step is performed in the presence of TFA at $0^{\circ} \mathrm{C}$, and the resulting trifluoroacetate salt which is frequently recovered after $\mathrm{Et}_{2} \mathrm{O}$ precipitation is used without further purification. Oligomers bearing up to 9 urea residues were obtained in high yields and in a sequence controlled manner using this synthesis route. However, to overcome solubility issues, and increase the efficacy of synthesis in the case of longer and diverse oligourea sequences, other strategies, such as convergent fragment condensation or stepwise solidphase synthesis techniques were developed.

\subsection{Fragment condensation}

Convergent coupling is a useful alternative to stepwise synthesis - whose efficacy starts to decrease beyond 10 residues due to solubility and/or purification issues - for accessing longer oligomers. Fragment condensation requires an oligourea segment to be activated as a succinimidyl carbamate at 
one end, prior to coupling to the terminal amine of a second oligourea segment. However, the activation of oligoureas is impaired by the formation of a cyclic biuret resulting from the attack of the formed succinimidyl carbamate by the nearest urea NH (Fremaux et al., 2011; Semetey, Didierjean, Briand, Aubry, \& Guichard, 2002). The introduction of a protecting group on this specific NH or the use of a $\mathrm{N}$-alkylated terminal residue instead (e.g. a proline derived monomer) circumvented this synthetic issue allowing activated oligoureas to be readily prepared. The fragment condensation step was found to proceed in good to high yield when using a pyrrolidine ring at the segment junction and long helical oligoureas up to 20 residues were obtained by iterative segment couplings(Fremaux et al., 2011).

\subsection{Solid phase synthesis of oligoureas}

We initially used Fmoc-protected monomers and standard protocols adapted from solid-phase peptide synthesis (SPPS) to prepare oligoureas on solid support(Gilles Guichard et al., 2000). Although short (up to seven residues) oligourea sequences were obtained in good yields and purities, the coupling steps required long reaction times (several hours) and a large excess of monomers (at least double couplings with 3 equiv. of monomers). Next, we thought to employ microwave irradiation, a widespread technique in SPPS to increase coupling rates and accelerate synthesis. However, we found that the Fmoc-protected monomers activated as $\mathrm{O}$-succinimidyl carbamates were not compatible with microwave irradiation leading to uncontrolled oligomerization on resin. The SPS of oligoureas using Boc-protected monomers and microwave assistance proved to be a much more robust strategy. Because the urea linkage formed by anchoring the first residue on MBHA-type resins was found to be sensitive to the acidic conditions required to cleave the Boc group, we introduced an isosteric $\gamma^{4}$-amino acid as the first residue to enable the formation of a stable amide bond onto the resin, prior to elongation of the oligourea sequence (Claudon et al., 2010). Excellent results in terms of synthesis efficiency (excess of monomers was substantially reduced and speed of synthesis was increased), and purity of crude products have been obtained. Yet the final HF cleavage from the resin renders this strategy not practical for routine syntheses in the laboratory. 
306 To combine both the convenient use of standard TFA-labile resins and the efficiency of microwave-

307 assisted coupling steps, we finally turned to monomers bearing azide as a masked amine for the SPS

308 of oligoureas (Douat-Casassus et al., 2012). Thus far, the best conditions identified for on-resin

309 reduction of azido-terminated oligoureas involve the use of trimethylphosphine with microwave

310 assistance. This method is compatible with automation and parallel synthesis and is now routinely used

311 in our laboratory to prepare oligoureas and related peptide-oligourea hybrids(Antunes, Douat, \&

312 Guichard, 2016; Cussol et al., 2021). The detailed synthetic procedures are reported in section 5.3.

\section{SYNTHETIC PROTOCOLS}

\section{$314 \quad 5.1$ Materials}

315

5.1.1 Reagents

316

\subsubsection{Chemicals}

317

Fmoc $\alpha$-amino acids

Isobutyl chloroformate (IBCF)

N-Methylmorpholine (NMM)

Sodium borohydride $\left(\mathrm{NaBH}_{4}\right)$

Trifluoroacetic acid (TFA)

323 Triphenylphosphine $\left(\mathrm{PPh}_{3}\right)$

324 Phthalimide

Diisopropyl azodicarboxylate (DIAD)

326 Methanesulfonyl chloride ( $\mathrm{MsCl})$ 
328 Imidazole-1-sulfonyl azide hydrochloride $\left(\mathrm{N}_{3} \mathrm{SO}_{2} \mathrm{Im} \cdot \mathrm{HCl}\right.$ ) (prepared as described in literature(Goddard-

329 Borger \& Stick, 2007, 2011)

330 Copper (II) sulfate pentahydrate $\left(\mathrm{CuSO}_{4} \cdot 5 \mathrm{H}_{2} \mathrm{O}\right)$

331 Triethylamine $\left(\mathrm{Et}_{3} \mathrm{~N}\right)$

332 Sodium azide $\left(\mathrm{NaN}_{3}\right)$

333 lodine $\left(I_{2}\right)$

334 Imidazole

335 Sodium chloride $(\mathrm{NaCl})$

336 Sodium bicarbonate $\left(\mathrm{NaHCO}_{3}\right)$

337 Potassium carbonate $\left(\mathrm{K}_{2} \mathrm{CO}_{3}\right)$

338 Potassium hydrogen sulfate $\left(\mathrm{KHSO}_{4}\right)$

339 Magnesium sulfate $\left(\mathrm{MgSO}_{4}\right)$

$340 \quad N, N$-diisopropylethylamine (DIEA)

341 Isopropyl isocyanate

342 Triisopropylsilane (TIS)

343 Piperidine

$344 N, N^{\prime}$-diisopropylcarbodiimide (DIC)

345 Ethyl-2-cyano-2-(hydroxyimino)acetate (Oxyma)

346 Trimethylphosphine solution (1M in tetrahydrofuran).

347 5.1.1.2 Resins

348 Rink Amide MBHA resin (Novabiochem $\# 8550030005$, loading of $0.52 \mathrm{mmol} / \mathrm{g}$ ). 
350 Dry DCM and THF are obtained by filtration through activated alumina using a dedicated purification 351 system (MBRAUN SPS-800) and should be used immediately. The other solvents are purchased from commercial sources and used without any further purification. Specific solvent grades are recommended for the solid phase synthesis: $N, N$-dimethylformamide (DMF, Carlo Erba \#P0343521, for peptide synthesis), dichloromethane (DCM, Carlo Erba \#412622000, HPLC grade), 1,4-dioxane (Carlo Erba \#338003) and acetonitrile (MeCN, Carlo Erba \#412409, HPLC grade), water (mQ grade).

\subsubsection{Equipment}

Magnetic stirrer with temperature sensor (Heidolph), Balance (Mettler Toledo), UV lamp (Vilber), Rotary evaporator (Buchi or Heidolph), Bath sonicator (Bioblock Scientific), High vacuum pump (RZ6, Vacuubrand) with a glass vacuum manifold and a cold finger, Combiflash purification system (Teledyne ISCO), $\mathrm{pH}$ 0-11 test paper (Labomoderne), CEM Discover Bio (manual microwave peptide synthesizer, CEM Corporation), CEM Liberty Blue (automated microwave peptide synthesizer, CEM Corporation), CEM polypropylene SPS reaction vessel ( $25 \mathrm{~mL}$, CEM Corporation), plastic syringes $(1,2$ and $5 \mathrm{~mL}$ ), micropipette (100 $\mu \mathrm{L}$, Eppendorf), frit column plate (Roland vetter laborbedarf OHG), Eppendorf tube (1.5 mL), falcon centrifuge tube $(15 \mathrm{~mL}$ ), centrifuge (Mega star 600R, VWR), vortex mixer (Top mix FB 15024, Fisher scientific), freeze dryer (VirTis BenchTop Pro, SP Scientific) with a vacuum pump (RC6, Vacuubrand), flask shaker (SF1, Stuart). RP-HPLC (reverse phase high performance liquid chromatography) to check purity was carried out on a Macherey-Nagel Nucleodur $100-3 \mathrm{C}_{18} \mathrm{ec}$ column $(3 \mu \mathrm{m}, 100 \times 4 \mathrm{~mm}$ ) at a flow rate of $1 \mathrm{~mL} / \mathrm{min}$ with a binary eluent system (solvent A: MilliQ water containing $0.1 \%(\mathrm{v} / \mathrm{v})$ TFA and solvent B: acetonitrile containing $0.1 \%(\mathrm{v} / \mathrm{v})$ TFA).

\subsection{Monomer preparation}

\subsubsection{Azide type monomers bearing the side chain at the ${ }^{\beta} \mathrm{C}$ position ( $\left.\mathrm{N}_{3}-\mathrm{Xaq}^{u}-\mathrm{OSu}\right)$}

372 The azide-type monomers bearing proteinogenic side chains are synthesized in 6 steps from the 
pathways have been developed depending on the nature of the side chain: path $A$ is recommended

375 for monomers without acid labile protecting group on the side chain; path B should be followed

376 otherwise. These monomers are usually synthesized in our laboratory on a 20 to $30 \mathrm{mmol}$ scale.

path A<smiles>[R]C(NC(=O)O)C(=O)O</smiles>

$$
\text { i) IBCF, NMM }
$$

THF, $-10^{\circ} \mathrm{C}$

ii) $\mathrm{NaBH}_{4}$

$\mathrm{H}_{2} \mathrm{O} / \mathrm{THF}, 0^{\circ} \mathrm{C}$

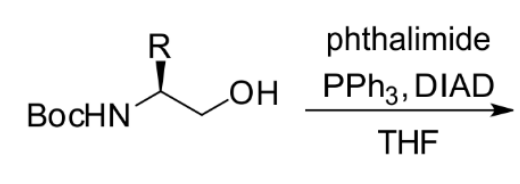<smiles>[R]C(CN1C(=O)c2ccccc2C1=O)NC(=O)OCc1ccccc1</smiles>

i) TFA, r.t

ii) $\mathrm{N}_{3} \mathrm{SO}_{2} \mathrm{Im} \cdot \mathrm{HCl}$ $\mathrm{K}_{2} \mathrm{CO}_{3}, \mathrm{CuSO}_{4}$ $\mathrm{MeCN} / \mathrm{H}_{2} \mathrm{O}$, r.t.<smiles>[R]C(N)CN1C(=O)c2ccccc2C1=O</smiles><smiles>[R]C([N])CN</smiles><smiles></smiles><smiles>[R]C(N)CNC(=O)ON1C(=O)CCC1=O</smiles>

$\mathrm{N}_{3}-\mathrm{Xaa}^{\mathrm{u}}-\mathrm{OSu}$

path B<smiles>[R]C(NC(F)F)C(=O)O</smiles>

i) IBCF, NMM THF, $-10^{\circ} \mathrm{C}$

ii) $\mathrm{NaBH}_{4}$ $\mathrm{H}_{2} \mathrm{O} / \mathrm{THF}, 0^{\circ} \mathrm{C}$<smiles>[R]C(CO)NC=O</smiles>

$\underset{\text { ii) } \mathrm{N}_{3} \mathrm{SO}_{2} \mathrm{Im} \cdot \mathrm{HCl}}{\longrightarrow}$<smiles>[R]C([NH])CO</smiles>
$\mathrm{K}_{2} \mathrm{CO}_{3}, \mathrm{CuSO}_{4}$ $\mathrm{MeCN} / \mathrm{H}_{2} \mathrm{O}$, r.t.

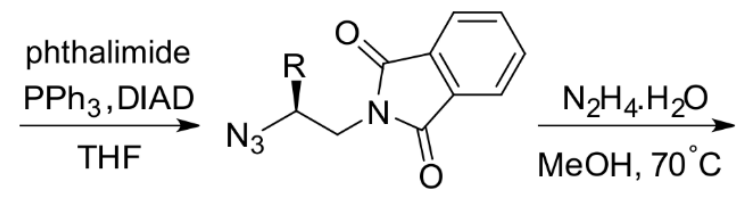<smiles>[R]C([N])CN</smiles><smiles></smiles><smiles>[R]C(N)CNC(=O)ON1C(=O)CCC1=O</smiles>

$\mathrm{N}_{3}-\mathrm{Xaa}^{\mathrm{u}}-\mathrm{OSu}$

Fig. 5. General synthetic procedure for the preparation of azide type monomers bearing side chain at the ${ }^{\beta} \mathrm{C}$ position, depending on the nature of the side chain. 
1. N-Boc (or Fmoc) $\alpha$-amino acid was dissolved in anhydrous THF (at $0.5 \mathrm{M}$ ) under $\mathrm{N}_{2}$ atmosphere and the solution was cooled down to $-20^{\circ} \mathrm{C}$ (in salt-ice bath). After addition of NMM (1.2 equiv.) and IBCF (1.2 equiv.), the mixture was stirred at $-10^{\circ} \mathrm{C}$, for $30 \mathrm{~min}$.

2. The resulting white suspension was then filtered off and washed with THF twice. The filtrate and washing solution were combined and added to a solution of $\mathrm{NaBH}_{4}(1.2$ equiv., $1.0 \mathrm{M})$ in water at $0^{\circ} \mathrm{C}$. The resulting mixture was stirred at room temperature for $2 \mathrm{~h}$.

3. The reaction mixture was then quenched by adding a $1 \mathrm{M} \mathrm{KHSO}_{4}$ solution. The THF was removed using rotary evaporation and the crude was dissolved in EtOAc. After phase separation, two additional extractions of the aqueous phase were performed with EtOAc. The organic layers were then combined and washed twice with a $1 \mathrm{M} \mathrm{KHSO}_{4}$ solution, then twice with a saturated solution of $\mathrm{NaHCO}_{3}$ followed by brine. The organic layer was then dried over $\mathrm{MgSO}_{4}$ and concentrated under reduced pressure to give the corresponding alcohol.

Note: The addition of THF filtrate to aqueous $\mathrm{NaBH}_{4}$ solution is accompanied by releasing of hydrogen gas.

\subsubsection{Procedure for the conversion of the alcohol into the corresponding phthalimide}

Timing: $12-24 \mathrm{~h}$.

Note: If you are following path $B$, the section 5.2.1.3 should be performed before 5.2.1.2.

4. Triphenylphosphine (1.2 equiv.) and phthalimide (1.2 equiv.) were dissolved in anhydrous THF (0.3 M), followed by dropwise addition of DIAD (1.2 equiv.) at $0^{\circ} \mathrm{C}$ under $\mathrm{N}_{2}$ atmosphere. The mixture was stirred for $10 \mathrm{~min}$.

5. $N$-Boc protected $\beta$-amino alcohol (in path $A)$ (1.0 equiv.) or $\beta$-azido alcohol (in path $B$ ) (1.0 equiv.) was dissolved in anhydrous THF (0.5 M).

6. The THF solution in step 5 was added to the reaction mixture at $0^{\circ} \mathrm{C}$ and then the reaction was allowed to reach room temperature. 
7. The reaction takes $2 \mathrm{~h}$ to overnight to go to completion (monitored by TLC). After completion, THF was evaporated under reduced pressure and the crude material was purified by flash chromatography.

\subsubsection{Procedure for the introduction of the azido group}

Timing: 1 day.

8. This step aims removing the protecting group on the amine. Please choose the suitable conditions according to the protecting group of the starting $\alpha$-amino acid.

Option $\boldsymbol{A}$ (removal of Boc group, path $\boldsymbol{A}$ ): The $N$-Boc protected $\beta$-amino phthalimide (1.0 equiv.) was dissolved in pure TFA and reaction was stirred at room temperature for 1 hour. Crude was concentrated and directly used in the next step.

Option B (removal of Fmoc group, path B): The $N$-Fmoc protected $\beta$-amino alcohol (1.0 equiv.) was dissolved in THF ( $0.2 \mathrm{M}$ ) followed by addition of DBU (1.1 equiv.). After 1 hour, the solvent was concentrated and crude was directly used in the next step.

9. The free amine or the corresponding TFA ammonium salt previously obtained was dissolved in a 1:1 mixture of $\mathrm{MeCN} / \mathrm{H}_{2} \mathrm{O}(0.1 \mathrm{M}) . \mathrm{K}_{2} \mathrm{CO}_{3}$ ( $\geq 1.5$ equiv.), $\mathrm{CuSO}_{4} \cdot 5 \mathrm{H}_{2} \mathrm{O}$ (0.01 equiv.) and $\mathrm{N}_{3} \mathrm{SO}_{2} \mathrm{Im} \cdot \mathrm{HCl}$ (1.2 equiv.) were added. Reaction was then stirred overnight at room temperature.

10. MeCN was evaporated and EtOAc was added to the remaining aqueous layer. The two layers were separated and the aqueous phase was extracted four times with EtOAc. Combined organic layers were washed with a $1 \mathrm{M} \mathrm{KHSO}_{4}$ solution three times and one time with brine. The organic layer was then dried over $\mathrm{MgSO}_{4}$ and concentrated under reduced pressure. The azide compound was then purified using flash column chromatography.

Caution: TFA is corrosive!!! Evaporation of TFA should be carried out on acid resistant equipment. 
Note 1: The diazotransfer reagent Imidazole-1-sulfonyl azide hydrochloride $\left(\mathrm{N}_{3} \mathrm{SO}_{2} \mathrm{Im} \cdot \mathrm{HCl}\right)$ is prepared according to the literature(Goddard-Borger \& Stick, 2007). Caution should be taken when preparing and handling this reagent(Goddard-Borger \& Stick, 2011).

433

434

Note 2: In step 9, the amount of $\mathrm{K}_{2} \mathrm{CO}_{3}$ should be adjusted to neutralize all the acid in the reaction mixture until a pH greater than 8 is reached.

\subsubsection{Procedure for the removal of the phthalimide group}

\section{Timing: $8 \mathrm{~h}$.}

11. To a solution of the phthalimide derivative in $\mathrm{MeOH}(0.1 \mathrm{M})$ was added hydrazine hydrate (3 equiv.). The reaction mixture was heated to reflux and heating was maintained for $4 \mathrm{~h}$.

12. The white precipitate was filtered off and $\mathrm{MeOH}$ was evaporated using rotary evaporation. The remaining mixture was dissolved in EtOAc and precipitate was removed by filtration. The filtrate was extracted twice with a $1 \mathrm{M} \mathrm{KHSO}_{4}$ solution from the organic phase, and the combined aqueous layers were washed twice with EtOAc.

13. Solid $\mathrm{K}_{2} \mathrm{CO}_{3}$ was then carefully added to the aqueous phase until pH 8 is reached. The basic amine is finally extracted with $\mathrm{DCM}$ four times, dried over $\mathrm{MgSO}_{4}$ and concentrated under reduced pressure.

Caution: The monomers corresponding to Ala, Val and Leu side chains are volatile, do not concentrate to dryness.

\subsubsection{Procedure for the preparation of succinimidyl azido-2-substituted-ethyl-carbamates}

\section{Timing: $5 \mathrm{~h}$.}

14. Disuccinimidyl carbonate (1.1 equiv.) dissolved in anhydrous $\mathrm{DCM}(0.3 \mathrm{M})$ was cooled to $0^{\circ} \mathrm{C}$. The amine obtained from the previous step was solubilized in anhydrous DCM $(0.2 \mathrm{M})$ and added dropwise to the disuccinimidyl carbonate solution. Reaction was then stirred for 3 hours and allowed to reach room temperature. 
15. After removal of DCM under rotary evaporation, the crude material was diluted in EtOAc, washed twice with a $1 \mathrm{M} \mathrm{KHSO}_{4}$ solution and once with brine. The organic layer was dried over $\mathrm{MgSO}_{4}$ and concentrated under reduced pressure.

16. The expected monomer was recovered as a solid after precipitation in a mixture $\mathrm{Et}_{2} \mathrm{O} /$ pentane.

\subsubsection{Example of monomer characterization}

$\mathbf{N}_{3}-$ Leu $^{u}-\mathrm{OSu}: \mathrm{mp} 92-94^{\circ} \mathrm{C} ;[\alpha]^{25}{ }_{\mathrm{D}}+49.3 ; t_{\mathrm{R}}=7.25$ min (gradient 10 to $100 \%$ of $\mathrm{MeCN}$ in $\mathrm{H}_{2} \mathrm{O}$ over 10 $\min ) ;{ }^{1} \mathrm{H} \mathrm{NMR}\left(\mathrm{CDCl}_{3}, 300 \mathrm{MHz}\right) \delta 5.69(\mathrm{t}, \mathrm{J}=6.0,1 \mathrm{H}), 3.65-3.56(\mathrm{~m}, 1 \mathrm{H}), 3.46(\mathrm{ddd}, \mathrm{J}=13.9,6.8,3.7$, $1 \mathrm{H}), 3.14(\mathrm{ddd}, \mathrm{J}=13.8,8.2,5.4,1 \mathrm{H}), 2.83(\mathrm{~s}, 4 \mathrm{H}), 1.87-1.70(\mathrm{~m}, 1 \mathrm{H}), 1.51(\mathrm{ddd}, \mathrm{J}=14.6,8.5,6.2,1 \mathrm{H}$ ), $1.35(\mathrm{ddd}, \mathrm{J}=13.9,8.1,5.6,1 \mathrm{H}), 0.96(\mathrm{~d}, \mathrm{~J}=6.6,6 \mathrm{H}) ;{ }^{13} \mathrm{C} \mathrm{NMR}\left(\mathrm{CDCl}_{3}, 75 \mathrm{MHz}\right) \delta 169.97,151.77,60.12$ 45.73, 40.74, 25.58, 25.00, 22.92, 22.19; HRMS (ESI-TOFMS) $\mathrm{m} / \mathrm{z}$ cald for $\mathrm{C}_{11} \mathrm{H}_{17} \mathrm{~N}_{5} \mathrm{O}_{4} \mathrm{Cl}[\mathrm{M}+\mathrm{Cl}]^{-}$ 318.0969, found 318.0978.

\section{<Insert Table 1 here>}

\subsubsection{Azide type monomers bearing the side chain at the ${ }^{\alpha} \mathrm{C}$ position $\left(\mathrm{N}_{3}-\mathrm{Xaq}^{u \alpha}-\mathrm{OSu}\right)$}

Two synthetic routes are used to prepare these $\alpha$-substituted monomers, starting either from Bocprotected or Fmoc-protected amino acids (Fig. 6). Path A corresponds to the synthesis using Bocprotected amino acids which are recommended for monomer without acid labile protective groups on the side chain. Path B should be used otherwise. Both synthetic routes are robust, even if a flash column chromatography has to be used to remove impurities after the deprotection step with DBU for the path $B$, while a simple precipitation is required for the path $A$. 
path A
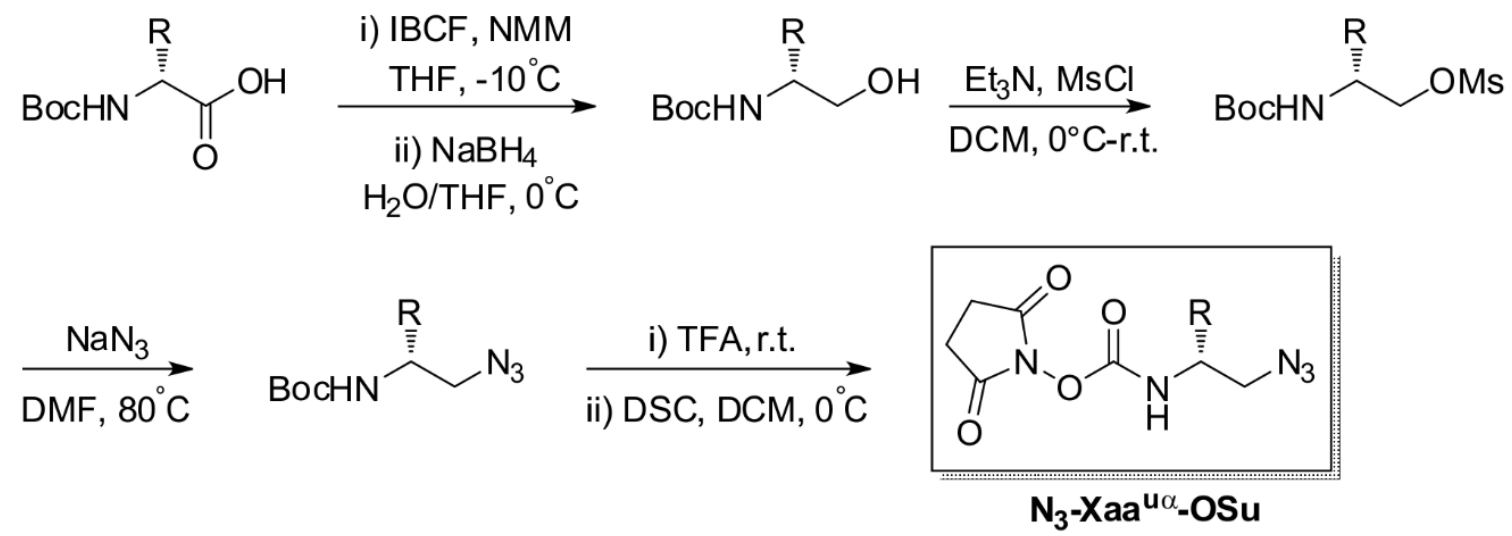

path B
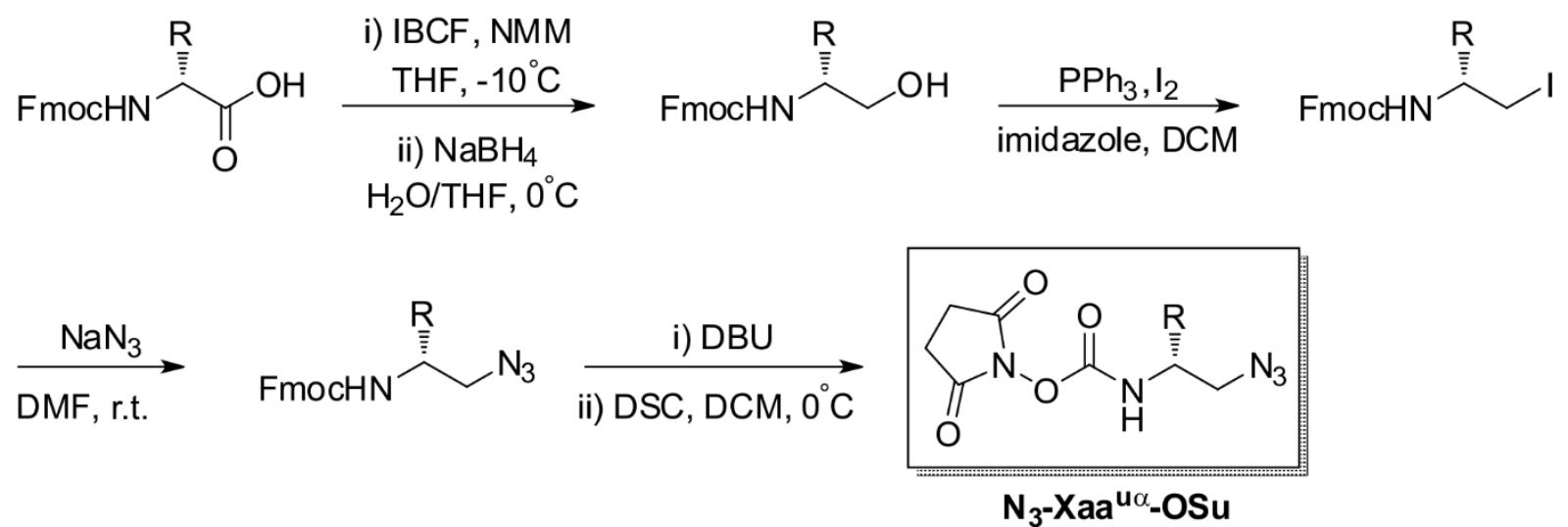
(L) configuration.

Timing: $8 \mathrm{~h}$

Fig. 6. General synthetic procedure for the preparation of azide type monomers bearing side chain at the ${ }^{\alpha} \mathrm{C}$ position with inversion of stereochemistry, depending on the nature of the side chain.

It is worth noting that substituting monomers whose side chain has been shifted to the ${ }^{\alpha} \mathrm{C}$ for canonical monomers (i.e. monomers bearing the side chain at the ${ }^{\beta} \mathrm{C}$ ) at discrete positions in an oligourea sequence is compatible with helix formation, provided that the two classes of monomers have opposite absolute configuration. Hence, the synthesis of Xaa ${ }^{\mathrm{u \alpha}}$ should start with $\alpha$-amino acids of $(D)$ configuration if the other Xaa" monomers of the sequence have been prepared from $\alpha$-amino acids of 
As previously described in section 5.2.1.1.

\subsubsection{Procedure for the mesylation of N-Boc- $\beta$-amino alcohol (path A)}

Timing: $24 \mathrm{~h}$

17. The $N$-Boc protected $\beta$-amino alcohol (1.0 equiv.) was dissolved in DCM ( $0.5 \mathrm{M})$ and cooled to $0^{\circ} \mathrm{C}$ under $\mathrm{Ar}^{-\mathrm{Et}_{3} \mathrm{~N}}$ (2.0 equiv.) was added and the mixture was stirred for $15 \mathrm{~min}$ at $0^{\circ} \mathrm{C}$. Then $\mathrm{MsCl}$ (1.1 equiv.) was added dropwise at $0^{\circ} \mathrm{C}$ and reaction mixture was allowed to reach room temperature and let to react overnight.

18. After removal of DCM by rotary evaporation, the crude material was diluted in EtOAc, washed successively twice with a $1 \mathrm{M} \mathrm{KHSO}_{4}$ solution and once with brine, dried over $\mathrm{MgSO}_{4}$ and concentrated under reduced pressure to afford the $N$-Boc protected $\beta$-amino methanesulfonate derivative.

5.2.2.3 Procedure for the preparation of tert-butyl (2-azido-1-substituted-ethyl)carbamate (Path A)

\section{Timing: $8 \mathrm{~h}$}

19. The $N$-Boc protected $\beta$-amino methanesulfonate derivative (1.0 equiv.) was dissolved in DMF (0.4 M). After addition of $\mathrm{NaN}_{3}\left(5.0\right.$ equiv.), reaction mixture was heated to $80^{\circ} \mathrm{C}$ and stirred for $5 \mathrm{~h}$.

20. The reaction medium was then diluted with EtOAc, washed four times with water and once with brine. Organic layer was then dried over $\mathrm{MgSO}_{4}$ and concentrated under reduced pressure. The tert-butyl (2-azido-1-substituted-ethyl)carbamate was obtained as a white solid after high vacuum drying.

5.2.2.4 Procedure for the preparation of succinimidyl (2-azido-1-substituted-ethyl)-carbamates (Path A)

Timing: $24 \mathrm{~h}$ 
21. The tert-butyl (2-azido-1-substituted-ethyl)carbamate (1.0 equiv.) was dissolved in pure TFA and let to react $30 \mathrm{~min}$.

22. TFA was removed using rotary evaporation, then the crude material was carefully neutralized using a saturated solution of $\mathrm{NaHCO}_{3}$.

23. The amine compound was then extracted using EtOAc five times. The combined organic layers were dried over $\mathrm{MgSO}_{4}$ and concentrated under reduced pressure to give the expected amine which was then directly used in the next step.

24. As previously described in section 5.2.1.5, the expected monomer was obtained as a solid.

Caution: TFA is corrosive!!! Evaporation of TFA should be carried out on acid resistant equipment.

\subsubsection{Procedure for the preparation of N-Fmoc $\beta$-iodoamine derivative (Path B)}

\section{Timing: $8 \mathrm{~h}$}

25. $\mathrm{I}_{2}$ (3.0 equiv.), $\mathrm{PPh}_{3}$ (3.0 equiv.) and imidazole (5.0 equiv.) were dissolved in $\mathrm{DCM}(1.0 \mathrm{M})$ and flushed with $\mathrm{N}_{2}$.

26. $N$-Fmoc protected $\beta$-amino alcohol was dissolved in DCM (1.0 M) and added to the reaction mixture. Reaction was then stirred for $5 \mathrm{~h}$.

27. The reaction medium was then washed twice with an aqueous solution of $\mathrm{Na}_{2} \mathrm{~S}_{2} \mathrm{O}_{3}(0.5 \mathrm{M})$ and once with brine. After flash column chromatography, the $N$-Fmoc $\beta$-iodoamine derivative compound was recovered as a solid and used directly in the next step.

\subsubsection{Procedure for preparation of N-Fmoc-amino azide compound (Path B)}

\section{Timing: $8 \mathrm{~h}$}

28. The $N$-Fmoc protected $\beta$-iodoamine (1.0 equiv.) was dissolved in DMF (0.4 M). After addition of $\mathrm{NaN}_{3}$ (5.0 equiv.), reaction mixture was stirred for $5 \mathrm{~h}$ at room temperature. 
29. The reaction medium was then diluted with EtOAc, washed four times with water and once with brine. Organic layer was then dried over $\mathrm{MgSO}_{4}$ and concentrated under reduced pressure. No silica gel purification was required. The $\mathrm{N}$-Fmoc protected amino azide was obtained as a solid after high vacuum drying.

5.2.2.7 Procedure for the preparation of succinimidyl 2-azido-1-substituted-ethyl-carbamates (Path B)

Timing: $24 \mathrm{~h}$

30. (9H-fluoren-9-yl)methyl (2-azido-1-substituted-ethyl)carbamate was dissolved in EtOAc (0.1 $\mathrm{M})$ and DBU (1.0 equiv.) was added. Reaction mixture was then stirred for $1 \mathrm{~h}$.

31. The crude material was concentrated and purified by flash chromatography (100\% EtOAc followed by $\mathrm{DCM} / \mathrm{MeOH} / \mathrm{Et}_{3} \mathrm{~N}$ 90:8:2). The expected amine was recovered and directly used in the next step.

32. Follow the description in section 5.2.1.5 to give expected building blocks as a solid.

$<$ Insert Table 2 here $>$

\subsection{Synthesis of oligourea based foldamers on solid support}

The methodology developed to synthesize water soluble oligourea based foldamers on solid support (homo-oligourea as well as hybrid peptide-oligourea or oligourea-peptide sequences) using azide-type monomers is reported here.

\subsubsection{Solid phase synthesis of oligoureas}

The synthesis of an amphiphilic oligourea foldamer designed to self-assemble in aqueous solution (H1 : $i \operatorname{Pr}^{\mathrm{u}} L^{\mathrm{u}} E^{\mathrm{u}} K^{\mathrm{u}} L^{\mathrm{u}}{ }^{\mathrm{u}} L^{\mathrm{u}} E^{\mathrm{u}} K^{\mathrm{u}} L^{\mathrm{u}} A^{\mathrm{u}} L^{\mathrm{u}}$ ) (Collie et al., 2015) is exemplified on a $50 \mu \mathrm{mol}$ scale (Fig. 7). Microwave assisted protocols (from 1 to 4 ) are carried out under $\mathrm{N}_{2}$ atmosphere using CEM Discover Bio system equipped with a fiber optic sensor for temperature control. In our experience, the protocols can be applied up to $150 \mu \mathrm{mol}$ scale with consistent efficiency. 


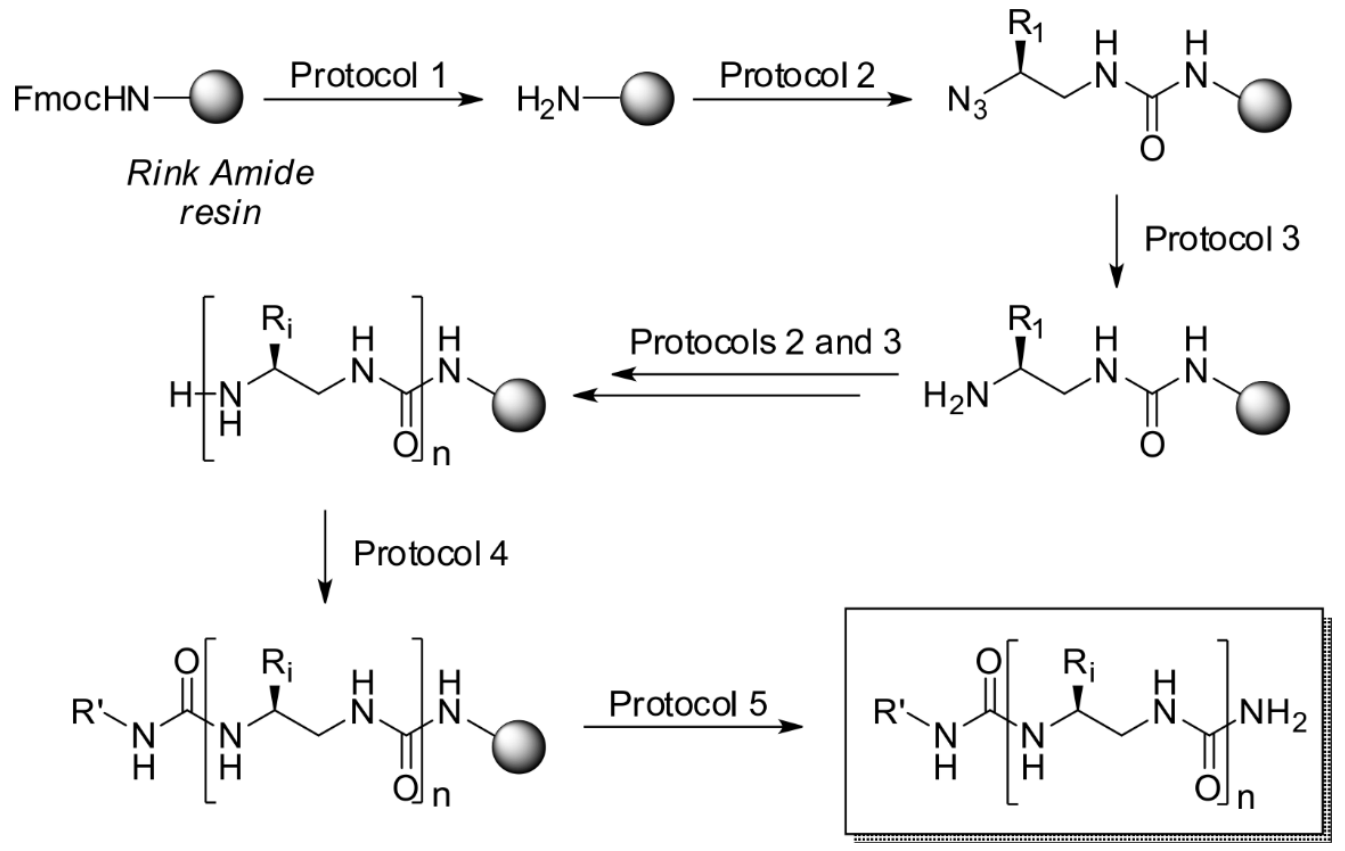

Fig. 7. General synthetic procedure for SPS of oligourea foldamers.

\subsubsection{Protocol 1 : Fmoc deprotection to activate the resin}

Timing: 2 h $10 \mathrm{~min}$

1. Add $96 \mathrm{mg}$ of Rink Amide MBHA resin $\left(50 \mu \mathrm{mol}\right.$ for $0.52 \mathrm{mmol} \cdot \mathrm{g}^{-1}$ loading) to the CEM polypropylene SPS reaction vessel.

2. Add $2 \mathrm{~mL}$ of DMF to the dried resin and wait $2 \mathrm{~h}$ for resin swelling.

3. Remove the solvent by filtration, add $3 \mathrm{~mL}$ of $20 \%$ piperidine/DMF $(\mathrm{v} / \mathrm{v})$, and then flush with $\mathrm{N}_{2}$.

4. Place the reaction vessel inside the microwave reactor and irradiate with microwaves (50 $\mathrm{W}$ maximum power, ramp to $50^{\circ} \mathrm{C}$, with 8 min hold time).

5. Take reaction vessel out of microwave reactor, filter the resin, and then wash the resin with 


\section{Timing: $1 \mathrm{~h}$}

6. Add $75 \mu \mathrm{mol}$ of $\mathrm{N}_{3}-\mathrm{Xaa}^{\mathrm{u}}$-OSu (1.5 equiv. relative to resin loading) to the $1.5 \mathrm{~mL}$ Eppendorf tube followed by adding $26 \mu \mathrm{L}$ of DIEA (3 equiv. relative to resin loading) and $1.5 \mathrm{~mL}$ of DMF.

7. Sonicate and vortex the Eppendorf tube to solubilize $\mathrm{N}_{3}-\mathrm{Xaa}{ }^{u}-\mathrm{OS} u$ well.

8. Transfer the $\mathrm{N}_{3}-\mathrm{Xaa}^{\mathrm{u}}$-OSu solution to the reaction vessel, rinse the Eppendorf tube with $1.5 \mathrm{~mL}$ of DMF to transfer residual solution to the reaction vessel, and then flush the reaction vessel with $\mathrm{N}_{2}$.

9. Place the reaction vessel inside the microwave reactor and irradiate with microwaves $(25 \mathrm{~W}$ maximum power, ramp to $70^{\circ} \mathrm{C}$, with 20 min hold time).

10. Take reaction vessel out of the microwave reactor, filter the resin, and then wash the resin successively with DMF ( $3 \mathrm{~mL}), \mathrm{DCM}(3 \times 3 \mathrm{~mL})$ and DMF $(2 \times 3 \mathrm{~mL})$.

11. Repeat Steps 6. to 10. once more.

Note: The completion of the coupling step can be assessed using a colorimetric test (chloranil test(Vojkovsky, 1995). The absence of free amino function should give a negative result with the resin beads being colorless.

\subsubsection{Protocol 3 : Azide reduction}

Timing: $50 \mathrm{~min}$

12. Wash the resin with a 70\% 1,4-dioxane/water solution (v/v) $(2 \times 3 \mathrm{~mL})$.

13. Add $0.5 \mathrm{~mL}$ of $1 \mathrm{M}$ trimethylphosphine in THF solution (10 equiv. relative to resin loading) to the resin followed by adding $2 \mathrm{~mL}$ of a $70 \%$ 1,4-dioxane/water solution $(\mathrm{v} / \mathrm{v})$, and then flush the reaction vessel with $\mathrm{N}_{2}$.

14. Place the reaction vessel inside the microwave reactor and irradiate with microwaves $(25 \mathrm{~W}$ maximum power, ramp to $70^{\circ} \mathrm{C}$, with $15 \mathrm{~min}$ hold time). 
15. Take reaction vessel out of microwave reactor, filter the resin, and then wash the resin with 70\% 1,4-dioxane/water (v/v) $(2 \times 3 \mathrm{~mL})$ and DMF $(3 \times 3 \mathrm{~mL})$.

16. Repeat Steps 12. to 15 . once more.

\subsubsection{Protocol 4 (optional): isopropyl urea capping of the N-terminal amine}

Timing: $40 \mathrm{~min}$

17. Add $15 \mu \mathrm{L}$ of isopropyl isocyanate (3 equiv. relative to resin loading) to the $1.5 \mathrm{~mL}$ Eppendorf tube followed by adding $44 \mu \mathrm{L}$ of DIEA (5 equiv. relative to resin loading) and $1.5 \mathrm{~mL}$ of DMF.

18. Transfer the solution to the reaction vessel, rinse the Eppendorf tube with $1.5 \mathrm{~mL}$ of DMF to transfer residual solution to the reaction vessel, and then flush the reaction vessel with $\mathrm{N}_{2}$.

19. Place the reaction vessel inside the microwave reactor and irradiate with microwaves $(25 \mathrm{~W}$ maximum power, ramp to $70^{\circ} \mathrm{C}$, with $10 \mathrm{~min}$ hold time).

20. Filter the resin and wash successively with DMF $(3 \mathrm{~mL}), \mathrm{DCM}(3 \times 3 \mathrm{~mL})$ and DMF $(2 \times 3 \mathrm{~mL})$.

21. Repeat Steps 17. to 20. once more.

\subsubsection{Protocol 5: Cleavage of the oligourea from the resin}

Timing: $3-8 \mathrm{~h}$

22. Transfer the resin into a $5 \mathrm{~mL}$ plastic syringe with a frit column plate and wash the resin with DCM $(5 \times 3 \mathrm{~mL})$.

23. Close syringe with a cap, add $3 \mathrm{~mL}$ of the cleavage cocktail (TFA/TIS/ $\mathrm{H}_{2} \mathrm{O}=95 / 2.5 / 2.5(\mathrm{v} / \mathrm{v} / \mathrm{v})$ ) to the resin, and then gently close the syringe with its plunger.

24. Shake the syringe for $2 \mathrm{~h}$ using mechanical shaker.

25. Filter the cleavage mixture to a round bottomed flask and rinse the resin with cleavage cocktail $(2 \times 0.5 \mathrm{~mL})$. 
26. Concentrate the combined filtrate in the round bottomed flask on a rotary evaporator with a bath temperature of $40^{\circ} \mathrm{C}$ to obtain a viscous oil.

27. Add $5 \mathrm{~mL}$ of $\mathrm{Et}_{2} \mathrm{O}$ into the oil to precipitate, and triturate the precipitate.

28. Transfer the mixture to a centrifugal tube and rinse the flask with $\mathrm{Et}_{2} \mathrm{O}(2 \times 3 \mathrm{~mL})$ to transfer residual mixture.

29. Centrifuge the mixture for $5 \mathrm{~min}$ with $4000 \mathrm{rpm}$ and remove the supernatant.

30. Add $10 \mathrm{~mL}$ of $\mathrm{Et}_{2} \mathrm{O}$ to disperse the precipitate, repeat Step 29. and dry the solid on a vacuum manifold.

31. Dissolve the solid in $20 \%$ acetonitrile/water ( $v / v)$, and freeze-dry it.

Note 1: The cleavage time at Step 24. can vary from 2 hours to 6 hours depending on sequences.

Note 2: Solid-phase synthesis (assembly on the resin and cleavage) of $\mathbf{H 1}$ was typically completed within 28 working hours.

\subsubsection{Solid phase synthesis of hybrid peptide-oligourea (PUH) or oligourea-peptide (UPH) sequences}

The synthesis of an amphiphilic peptide-oligourea block co-foldamer designed to self-assemble (PUH : ALKEIAYAL ${ }^{u} E{ }^{u} E^{u} L^{u}{ }^{u} Q^{u} L^{u}$ ) is exemplified here on a $50 \mu \mathrm{mol}$ scale (Fig. 8). The elongation of the peptide part of the hybrid sequences is accomplished under $\mathrm{N}_{2}$ atmosphere using automated solid phase peptide synthesizer with microwaves assistance (CEM Liberty Blue system) equipped with a fiber optic sensor for temperature control. The peptide part can be incorporated regardless of its position in the sequence (before (e.g. UPH), after (e.g. PUH) or between the oligourea part). For the oligourea segment, the same protocols as described in the previous section are used. In our experience, the protocols can be applied up to $150 \mu \mathrm{mol}$ scale with consistent efficiency. 


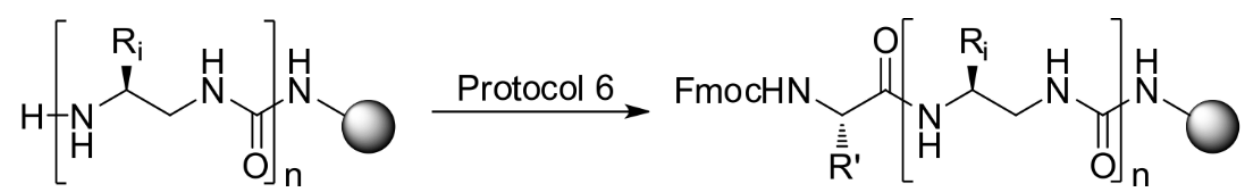

Oligourea loaded resin

Protocol 7

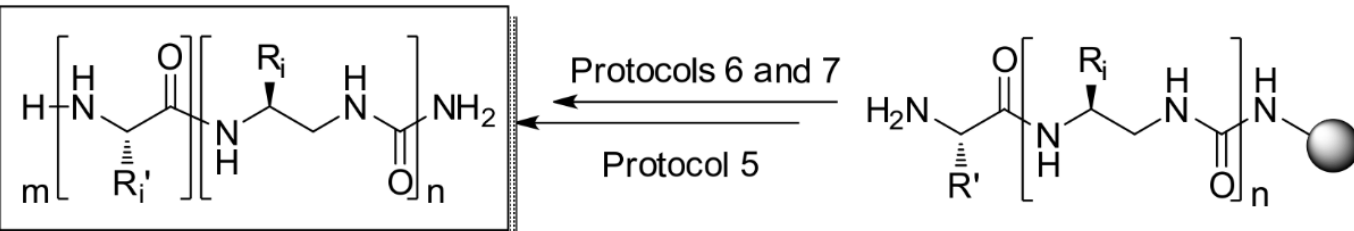

634

PUH

Fig. 8. General synthetic procedure for SPS of peptide-oligourea hybrid foldamers (PUH).

636

637

638

639

640

641

642

643

644

645

646

647

648

649

650

\subsubsection{Protocol 6: Peptide coupling}

Timing: $5 \mathrm{~min}$

32. Add $1.5 \mathrm{~mL}$ of $0.2 \mathrm{M}$ Fmoc- $\alpha-\mathrm{Xaa}-\mathrm{OH}$ in DMF (6 equiv. relative to resin loading) to the resin followed by adding $0.6 \mathrm{~mL}$ of $0.5 \mathrm{M} \mathrm{DIC}$ in DMF (6 equiv. relative to resin loading) and $0.3 \mathrm{~mL}$ of $1 \mathrm{M}$ Oxyma in DMF (6 equiv. relative to resin loading).

33. Irradiate with microwaves $\left(170 \mathrm{~W}\right.$ maximum power, ramp to $75^{\circ} \mathrm{C}$, with $15 \mathrm{~s}$ hold time $+30 \mathrm{~W}$ maximum power, ramp to $90^{\circ} \mathrm{C}$, with $110 \mathrm{~s}$ hold time)

34. Filter the resin and wash with DMF (2 mL).

35. Repeat steps 32. to 34. once more

\subsubsection{Protocol 7: Fmoc deprotection}

Timing: $5 \mathrm{~min}$

36. Add $3 \mathrm{~mL}$ of $20 \%$ piperidine/DMF $(\mathrm{v} / \mathrm{v})$ to the resin

37. Irradiate with microwaves $\left(155 \mathrm{~W}\right.$ maximum power, ramp to $75^{\circ} \mathrm{C}$, with $15 \mathrm{~s}$ hold time $+30 \mathrm{~W}$ maximum power, ramp to $90^{\circ} \mathrm{C}$, with $50 \mathrm{~s}$ hold time) 
Note: Automated-assisted synthesis (assembly on the resin and cleavage) of PUH and UPH was typically completed within $16-20$ working hours.

654

\subsubsection{Purification and characterization of oligourea-based foldamers}

656 Analytical RP-HPLC (Fig. 9A-B) and LC-MS (liquid chromatography-mass spectrometry) (Fig. 9C) are 657 used to evaluate the purity of the crude product and confirm the identity of the expected compound 658 after cleavage from the resin.

659 Purification via preparative RP-HPLC is performed on a Macherey-Nagel Nucleodur $100-5 \mathrm{C}_{18} \mathrm{HTec}$ 660 column $(5 \mu \mathrm{m}, 250 \times 21 \mathrm{~mm})$ at a flow rate of $20 \mathrm{~mL} / \mathrm{min}$ with the same binary eluent system as 661 analytical RP-HPLC. Gradients and running time were optimized for each sequence. For example, $\mathbf{H} \mathbf{1}$ is 662 purified using a gradient of $30 \%$ to $70 \%$ solvent B over $20 \mathrm{~min}$. In addition to the primary 663 characterization using mass spectrometry, conformational analysis and structural characterization in 664 solution or solid state can be accomplished using NMR, CD, crystallography and others. 
(A) Oligourea $\mathrm{H} 1$ (iPruLuEuKuLuYuLuEuKuLUAULu)

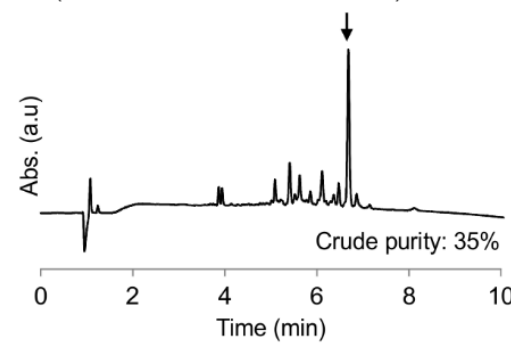

(B) $\mathrm{H} 1$

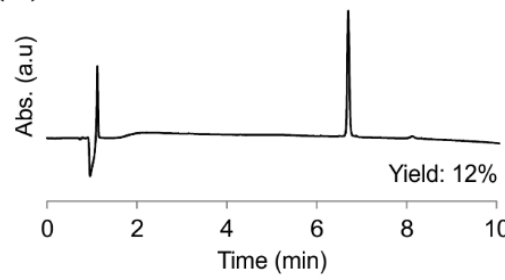

(C) $\mathrm{H} 1$

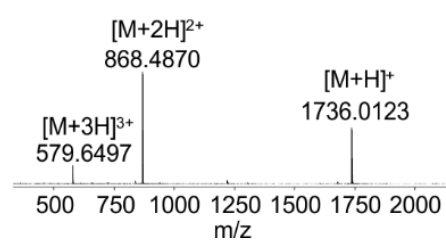

Peptide-Urea Hybrid PUH

(ALKEIAYALLEuEuLuQuLu)

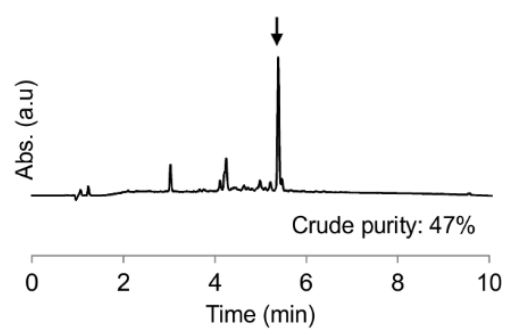

PUH

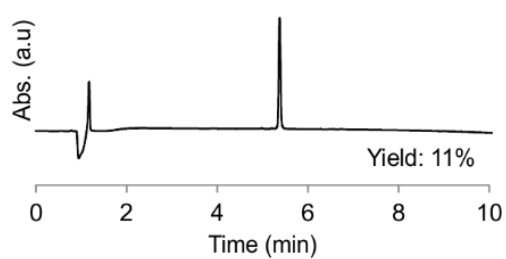

PUH

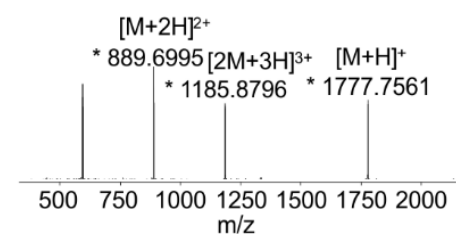

Urea-Peptide Hybrid UPH

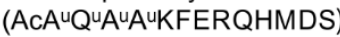

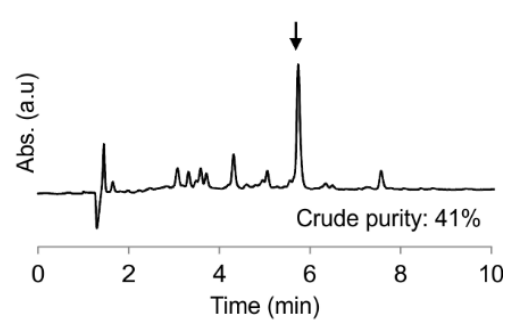

UPH

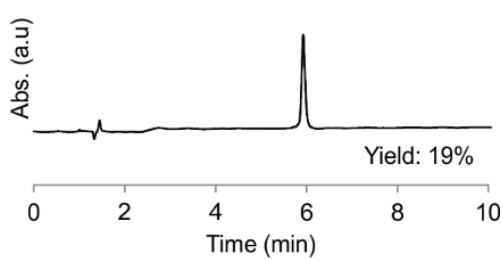

UPH

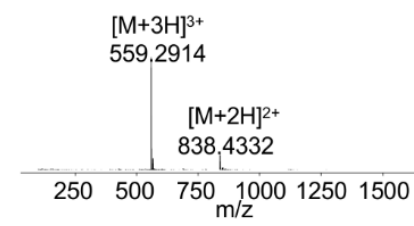

Fig. 9. Analytical HPLC profiles (A) before, and (B) after purification. (C) mass spectrometry analysis of foldamers H1, PUH and UPH. Crude purities are determined from peak area percentages. Arrows in (A) indicate peaks corresponding to the desired products. Gradients of $15 \%$ to $30 \%$ solvent B were applied for analytical HPLC of UPH while the standard gradient of $10 \%$ to $100 \%$ solvent B were applied for $\mathrm{H} 1$ and PUH.

\subsubsection{Troubleshooting}

The above-mentioned protocols generally result in good to high crude purities as shown in Fig. 9A.

However, in the specific case of oligourea-peptide hybrids (in contrast to peptide-oligourea hybrids), we observed that some sequences yield poor results with a low purity of the crude product. A more detailed analysis following intermediate cleavage at different steps of the synthesis reveals the formation of a byproduct after each azide reduction step, whose mass is higher than the expected amine by a value of $26 \mathrm{Da}$. The current hypothesis based on NMR and MS analysis is that a competitive cyclization occurs concomitantly with the reduction leading to a biuret formation, which ends further elongation of the sequence. Varying either the nature of the phosphine or the protecting group of the monomer (e. g. using Fmoc-protected monomer instead of azido-type) may help improving the overall 
efficiency of the synthesis. Investigations are currently ongoing to better identify sequences that may cause problems, and develop a more robust protocol for such "difficult" sequences.

\section{CONCLUDING REMARKS AND FUTURE DIRECTIONS}

The access to a large repertoire of monomeric units whose molecular diversity extends beyond that of proteinogenic side chains, together with robust automated SPS methods have been instrumental in the development of oligourea foldamers and their applications (molecular recognition, catalysis, disruption of PPI, ...). The combination of automation and microwave assistance considerably reduces the duration of the synthesis while enabling parallel synthesis and access to foldamer libraries. Moreover, the possibility to generate chimeric helices by combining peptide and oligourea backbones in a single strand further expands the range of applications of oligoureas as $\alpha$-helix mimics. Although the reported protocols allow smooth syntheses of a large number of homooligourea and hybrid sequences, we identified some "difficult sequences" while preparing oligourea-peptide chimeras. Continuous improvement of the synthesis of hybrid foldamer-peptide sequences is justified by the recent finding that the replacement of a short $\alpha$-helical segment within a bioactive peptide by an oligourea insert may yield peptide analogues with increased resistance to proteolytic degradation and prolonged duration of action in vivo. Finally, oligourea chemistry is versatile enough to be combined with other known peptide stabilization methods such as macrocyclization or lipidation to further increase helical content and potency of bioactive peptides.

\section{ACKNOWLEDGEMENTS}

This work was supported by the Agence Nationale de la Recherche (ANR) grants ANR-15-CE07-0010, ANR-17-CE07-0020 and ANR-18-CE07-0018-01. Postdoctoral fellowships to S.H.Y. from IdEx Bordeaux (ANR-10-IDEX-03-02), a program of the French government managed by ANR and to B.L. from the Conseil Régional de Nouvelle-Aquitaine (2017-1R10115) are gratefully acknowledged. We also thank Ureka Pharma for generously supporting our research in the field of urea oligomers. 


\section{REFERENCES}

709

710

711

712

713

714

715

716

717

718

719

720

721

722

723

724

Antunes, S., Douat, C., \& Guichard, G. (2016). Solid-Phase Synthesis of Hybrid Urea Oligomers Containing Conservative Thiourea Mutations. European Journal of Organic Chemistry, 2016(12), 2131-2138. doi:10.1002/ejoc.201600177

Azzarito, V., Long, K., Murphy, N. S., \& Wilson, A. J. (2013). Inhibition of [alpha]-helix-mediated proteinprotein interactions using designed molecules. Nature Chemistry, 5(3), 161-173. doi:10.1038/nchem.1568

Bécart, D., Diemer, V., Salaün, A., Oiarbide, M., Nelli, Y. R., Kauffmann, B., et al. (2017). Helical Oligourea Foldamers as Powerful Hydrogen Bonding Catalysts for Enantioselective C-C BondForming Reactions. Journal of the American Chemical Society, 139(36), 12524-12532. doi:10.1021/jacs.7b05802

Boersma, M. D., Haase, H. S., Peterson-Kaufman, K. J., Lee, E. F., Clarke, O. B., Colman, P. M., et al. (2011). Evaluation of Diverse $\alpha / \beta$-Backbone Patterns for Functional $\alpha$-Helix Mimicry: Analogues of the Bim BH3 Domain. Journal of the American Chemical Society, 134(1), 315-323. doi:10.1021/ja207148m

Bornerie, M., Brion, A., Guichard, G., Kichler, A., \& Douat, C. (2021). Delivery of siRNA by tailored cellpenetrating urea-based foldamers. Chemical Communications. doi:10.1039/D0CC06285E

Burgess, K., Shin, H., \& Linthicum, D. S. (1995). Solid-Phase Syntheses of Unnatural Biopolymers Containing Repeating Urea Units. Angewandte Chemie - International Edition, 34(8), 907-909. doi:10.1002/anie.199509071

Checco, J. W., \& Gellman, S. H. (2016). Targeting recognition surfaces on natural proteins with peptidic foldamers. Current Opinion in Structural Biology, 39, 96-105. doi:10.1016/j.sbi.2016.06.014

Checco, J. W., Lee, E. F., Evangelista, M., Sleebs, N. J., Rogers, K., Pettikiriarachchi, A., et al. (2015). $\alpha / \beta-$ Peptide Foldamers Targeting Intracellular Protein-Protein Interactions with Activity in Living 
Cells. Journal of the American Chemical Society, 137(35), 11365-11375. doi:10.1021/jacs.5b05896

Cheloha, R. W., Maeda, A., Dean, T., Gardella, T. J., \& Gellman, S. H. (2014). Backbone modification of a polypeptide drug alters duration of action in vivo. Nature Biotechnology, 32(7), 653-655. doi:10.1038/nbt.2920

Claudon, P., Violette, A., Lamour, K., Decossas, M., Fournel, S., Heurtault, B., et al. (2010). Consequences of Isostructural Main-Chain Modifications for the Design of Antimicrobial Foldamers: Helical Mimics of Host-Defense Peptides Based on a Heterogeneous Amide/Urea Backbone. Angewandte Chemie - International Edition, 49(2), 333-336. doi:10.1002/anie.200905591

Collie, G. W., Bailly, R., Pulka-Ziach, K., Lombardo, C. M., Mauran, L., Taib-Maamar, N., et al. (2017). Molecular Recognition within the Cavity of a Foldamer Helix Bundle: Encapsulation of Primary Alcohols in Aqueous Conditions. Journal of the American Chemical Society, 139(17), 61286137. doi:10.1021/jacs.7b00181

Collie, G. W., Pulka-Ziach, K., \& Guichard, G. (2016). In situ iodination and X-ray crystal structure of a foldamer helix bundle. Chemical Communications (Cambridge), 52(6), 1202-1205. doi:10.1039/c5cc07916k

Collie, G. W., Pulka-Ziach, K., \& Guichard, G. (2016). Surfactant-facilitated crystallisation of watersoluble foldamers. Chemical Science, 7(5), 3377-3383. doi:10.1039/c6sc00090h

Collie, G. W., Pulka-Ziach, K., Lombardo, C. M., Fremaux, J., Rosu, F., Decossas, M., et al. (2015). Shaping quaternary assemblies of water-soluble non-peptide helical foldamers by sequence manipulation. Nature Chemistry, 7(11), 871-878. doi:10.1038/nchem.2353

Cussol, L., Mauran-Ambrosino, L., Buratto, J., Belorusova, A. Y., Neuville, M., Osz, J., et al. (2021). Structural Basis for $\alpha$-Helix Mimicry and Inhibition of Protein-Protein Interactions with Oligourea Foldamers. Angewandte Chemie International Edition, 60(5), 2296-2303. doi:doi.org/10.1002/anie.202008992 
Diemer, V., Fischer, L., Kauffmann, B., \& Guichard, G. (2016). Anion Recognition by Aliphatic Helical Oligoureas. Chemistry - A European Journal, 22(44), 15684-15692. doi:10.1002/chem.201602481

Douat-Casassus, C., Pulka, K., Claudon, P., \& Guichard, G. (2012). Microwave-Enhanced Solid-Phase Synthesis of N,N '-Linked Aliphatic Oligoureas and Related Hybrids. Organic Letters, 14(12), 3130-3133. doi:10.1021/ol3012106

Douat, C., Aisenbrey, C., Antunes, S., Decossas, M., Lambert, O., Bechinger, B., et al. (2015). A CellPenetrating Foldamer with a Bioreducible Linkage for Intracellular Delivery of DNA. Angewandte Chemie - International Edition, 54(38), 11133-11137. doi:10.1002/anie.201504884

Douat, C., Bornerie, M., Antunes, S., Guichard, G., \& Kichler, A. (2019). Hybrid Cell-Penetrating Foldamer with Superior Intracellular Delivery Properties and Serum Stability. Bioconjugate Chemistry, 30(4), 1133-1139. doi:10.1021/acs.bioconjchem.9b00075

Ferrand, Y., \& Huc, I. (2018). Designing Helical Molecular Capsules Based on Folded Aromatic Amide Oligomers. Accounts of Chemical Research, 51(4), 970-977. doi:10.1021/acs.accounts.8b00075

Fischer, L., Claudon, P., Pendem, N., Miclet, E., Didierjean, C., Ennifar, E., et al. (2010). The Canonical Helix of Urea Oligomers at Atomic Resolution. Insight Into Folding-induced Axial Organization. Angewandte Chemie - International Edition, 49(6), 1067-1070. doi:10.1002/anie.200905592

Fischer, L., \& Guichard, G. (2010). Folding and self-assembly of aromatic and aliphatic urea oligomers: Towards connecting structure and function. Organic \& Biomolecular Chemistry, 8(14), 31013117. doi:10.1039/c001090a

Fremaux, J., Fischer, L., Arbogast, T., Kauffmann, B., \& Guichard, G. (2011). Condensation Approach to Aliphatic Oligourea Foldamers: Helices with $\mathrm{N}$-(pyrrolidin-2-ylmethyl)ureido Junctions. Angewandte Chemie - International Edition, 50, 11382-11385. doi:10.1002/anie.201105416 
Fremaux, J., Kauffmann, B., \& Guichard, G. (2014). Synthesis and Folding Propensity of Aliphatic Oligoureas Containing Repeats of Proline-Type Units. Journal of Organic Chemistry, 79(12), 5494-5502. doi:10.1021/jo5006075

Fremaux, J., Mauran, L., Pulka-Ziach, K., Kauffmann, B., Odaert, B., \& Guichard, G. (2015). $\alpha$-PeptideOligourea Chimeras: Stabilization of Short $\alpha$-Helices by Non-Peptide Helical Foldamers. Angewandte Chemie - International Edition, 54(34), 9816-9820. doi:10.1002/anie.201500901

Fremaux, J., Venin, C., Mauran, L., Zimmer, R., Koensgen, F., Rognan, D., et al. (2019). Ureidopeptide GLP-1 analogues with prolonged activity in vivo via signal bias and altered receptor trafficking. Chemical Science, 10(42), 9872-9879. doi:10.1039/C9SC02079A

Fremaux, J., Venin, C., Mauran, L., Zimmer, R. H., Guichard, G., \& Goudreau, S. R. (2019). Peptideoligourea hybrids analogue of GLP-1 with improved action in vivo. Nature Communications, 10(1), 924. doi:10.1038/s41467-019-08793-y

Gan, Q., Wang, X., Kauffmann, B., Rosu, F., Ferrand, Y., \& Huc, I. (2017). Translation of rod-like template sequences into homochiral assemblies of stacked helical oligomers. Nature Nanotechnology, 12(5), 447-452. doi:10.1038/nnano.2017.15

Gellman, S. H. (1998). Foldamers: A Manifesto. Accounts of Chemical Research, 31(4), 173-180. doi:10.1021/ar960298r

Goddard-Borger, E. D., \& Stick, R. V. (2007). An Efficient, Inexpensive, and Shelf-Stable Diazotransfer Reagent: Imidazole-1-sulfonyl Azide Hydrochloride. Organic Letters, 9(19), 3797-3800. doi:10.1021/ol701581g

Goddard-Borger, E. D., \& Stick, R. V. (2011). An Efficient, Inexpensive, and Shelf-Stable Diazotransfer Reagent: Imidazole-1-sulfonyl Azide Hydrochloride. Organic Letters, 13(9), 2514-2514. doi:10.1021/ol2007555

Goodman, C. M., Choi, S., Shandler, S., \& DeGrado, W. F. (2007). Foldamers as versatile frameworks for the design and evolution of function. Nature Chemical Biology, 3(5), 252-262. doi:10.1038/nchembio876 
Gopalakrishnan, R., Frolov, A. I., Knerr, L., Drury, W. J., \& Valeur, E. (2016). Therapeutic Potential of Foldamers: From Chemical Biology Tools To Drug Candidates? Journal of Medicinal Chemistry, 59(21), 9599-9621. doi:10.1021/acs.jmedchem.6b00376

Guichard, G., \& Huc, I. (2011). Synthetic foldamers. Chemical Communications (Cambridge), 47(21), 5933-5941. doi:10.1039/c1cc11137j

Guichard, G., Semetey, V., Didierjean, C., Aubry, A., Briand, J.-P., \& Rodriguez, M. (1999). Effective Preparation of O-Succinimidyl-2- (tert-butoxycarbonylamino)ethylcarbamate Derivatives from \&\#x03B2;-Amino Acids. Application to the Synthesis of Urea-Containing Pseudopeptides and Oligoureas. Journal of Organic Chemistry, 64(23), 8702-8705. doi:10.1021/jo990092e

Guichard, G., Semetey, V., Rodriguez, M., \& Briand, J.-P. (2000). Solid phase synthesis of oligoureas using O-succinimidyl-(9H-fluoren-9-ylmethoxycarbonylamino)ethylcarbamate derivatives as activated monomers. Tetrahedron Letters, 41(10), 1553-1557. doi:10.1016/s00404039(99)02353-9

Horne, W. S., \& Grossmann, T. N. (2020). Proteomimetics as protein-inspired scaffolds with defined tertiary folding patterns. Nature Chemistry, 12(4), 331-337. doi:10.1038/s41557-020-0420-9

Horne, W. S., Johnson, L. M., Ketas, T. J., Klasse, P. J., Lu, M., Moore, J. P., et al. (2009). Structural and biological mimicry of protein surface recognition by $\alpha / \beta$-peptide foldamers. Proceedings of the National Academy of Sciences of the United States of America, 106(35), 14751-14756. doi:10.1073/pnas.0902663106

Johnson, L. M., Barrick, S., Hager, M. V., McFedries, A., Homan, E. A., Rabaglia, M. E., et al. (2014). A Potent $\alpha / \beta$-Peptide Analogue of GLP-1 with Prolonged Action in Vivo. Journal of the American Chemical Society, 136(37), 12848-12851. doi:10.1021/ja507168t

Johnson, L. M., \& Gellman, S. H. (2013). Chapter Nineteen - $\alpha$-Helix Mimicry with $\alpha / \beta$-Peptides. In E. K. Amy (Ed.), Methods Enzymol. (Vol. 523, pp. 407-429): Academic Press.

Kim, J.-M., Bi, Y., Paikoff, S. J., \& Schultz, P. G. (1996). The solid phase synthesis of oligoureas. Tetrahedron Lett., 37(30), 5305-5308. 
Kritzer, J. A., Hodsdon, M. E., \& Schepartz, A. (2005). Solution structure of a [beta]-peptide ligand for hDM2. Journal of the American Chemical Society, 127, 4118-4119. doi:10.1021/ja042933r

Kritzer, J. A., Stephens, O. M., Guarracino, D. A., Reznik, S. K., \& Schepartz, A. (2005). [beta]-Peptides as inhibitors of protein-protein interactions. Bioorganic \& Medicinal Chemistry, 13, 11-16. doi:10.1016/j.bmc.2004.09.009

Le Grel, P., \& Guichard, G. (2007). Foldamers: Structure, Properties, and Applications. In S. Hecht \& I. Huc (Eds.), Foldamers: Structure, Properties, and Applications (pp. 35-74). Weinheim: WileyVCH.

Lee, E. F., Sadowsky, J. D., Smith, B. J., Czabotar, P. E., Peterson-Kaufman, K. J., Colman, P. M., et al. (2009). High-Resolution Structural Characterization of a Helical $\alpha / \beta$-Peptide Foldamer Bound to the Anti-Apoptotic Protein Bcl-xL. Angew. Chem. Int. Ed. Engl., 48(24), 4318-4322. doi:10.1002/anie.200805761

Legrand, B., André, C., Wenger, E., Didierjean, C., Averlant-Petit, M. C., Martinez, J., et al. (2012). Robust Helix Formation in a New Family of Oligoureas Based on a Constrained Bicyclic Building Block. Angewandte Chemie - International Edition, 51(45), 11267-11270. doi:10.1002/anie.201205842

Liu, S., Cheloha, R. W., Watanabe, T., Gardella, T. J., \& Gellman, S. H. (2018). Receptor selectivity from minimal backbone modification of a polypeptide agonist. Proceedings of the National Academy of Sciences of the United States of America, 115(49), 12383-12388. doi:10.1073/pnas.1815294115

Liu, S., Jean-Alphonse, F. G., White, A. D., Wootten, D., Sexton, P. M., Gardella, T. J., et al. (2019). Use of Backbone Modification To Enlarge the Spatiotemporal Diversity of Parathyroid Hormone Receptor-1 Signaling via Biased Agonism. Journal of the American Chemical Society, 141(37), 14486-14490. doi:10.1021/jacs.9b04179 
858 Lombardo, C. M., Collie, G. W., Pulka-Ziach, K., Rosu, F., Gabelica, V., Mackereth, C. D., et al. (2016). Anatomy of an Oligourea Six-Helix Bundle. Journal of the American Chemical Society, 138(33), 10522-10530. doi:10.1021/jacs.6b05063

Lombardo, C. M., Kumar, V., Douat, C., Rosu, F., Mergny, J. L., Salgado, G. F., et al. (2019). Design and Structure Determination of a Composite Zinc Finger Containing a Nonpeptide Foldamer Helical Domain. Journal of the American Chemical Society, 141(6), 2516-2525. doi:10.1021/jacs.8b12240

Mauran, L., Kauffmann, B., Odaert, B., \& Guichard, G. (2016). Stabilization of an $\alpha$-helix by short adjacent accessory foldamers. Comptes Rendus Chimie, 19(1-2), 123-131. doi:10.1016/j.crci.2015.07.003

Mbianda, J., Bakail, M., André, C., Moal, G., Perrin, M. E., Guerois, R., et al. (2020). Optimal Anchoring of a Urea-based Foldamer Inhibitor of ASF1 Histone Chaperone Through Backbone Plasticity. ChemRXiv, 10.26434/chemrxiv.12624722.v12624721. doi:10.26434/chemrxiv.12624722.v1

Michel, J., Harker, E. A., Tirado-Rives, J., Jorgensen, W. L., \& Schepartz, A. (2009). In Silico Improvement of beta3-peptide inhibitors of p53 x hDM2 and p53 x hDMX. Journal of the American Chemical Society, 131(18), 6356-6357. doi:10.1021/ja901478e

Milbeo, P., Simon, M., Didierjean, C., Wenger, E., Aubert, E., Martinez, J., et al. (2020). A bicyclic unit reversal to stabilize the $12 / 14$-helix in mixed homochiral oligoureas. Chemical Communications, 56(57), 7921-7924. doi:10.1039/D0CC02902E

Nelli, Y.-R., Douat-Casassus, C., Claudon, P., Kauffmann, B., Didierjean, C., \& Guichard, G. (2012). An activated building block for the introduction of the histidine side chain in aliphatic oligourea foldamers. Tetrahedron, 68(23), 4492-4500. doi:10.1016/j.tet.2011.11.066

Nelli, Y. R., Antunes, S., Salaün, A., Thinon, E., Massip, S., Kauffmann, B., et al. (2015). Isosteric Substitutions of Urea to Thiourea and Selenourea in Aliphatic Oligourea Foldamers: SiteSpecific Perturbation of the Helix Geometry. Chemistry - A European Journal, 21(7), 2870-2880. doi:10.1002/chem.201405792 
Nelli, Y. R., Fischer, L., Collie, G. W., Kauffmann, B., \& Guichard, G. (2013). Structural characterization of short hybrid urea/carbamate (U/C) foldamers: A case of partial helix unwinding. Biopolymers (Pept Sci) 100(6), 687-697. doi:10.1002/bip.22302

Pappas, C. G., Mandal, P. K., Liu, B., Kauffmann, B., Miao, X., Komáromy, D., et al. (2020). Emergence of low-symmetry foldamers from single monomers. Nature Chemistry, 12(12), 1180-1186. doi:10.1038/s41557-020-00565-2

Pasco, M., Dolain, C., \& Guichard, G. (2017). Foldamers in Medicinal Chemistry. In J. L. Atwood (Ed.), Comprehensive Supramolecular Chemistry II (Vol. 5, pp. 89-125). Oxford: Elsevier.

Pendem, N., Douat, C., Claudon, P., Laguerre, M., Castano, S., Desbat, B., et al. (2013). Helix-Forming Propensity of Aliphatic Urea Oligomers Incorporating Noncanonical Residue Substitution Patterns. J. Am. Chem. Soc., 135(12), 4884-4892. doi:10.1021/ja401151v

Pendem, N., Nelli, Y. R., Douat, C., Fischer, L., Laguerre, M., Ennifar, E., et al. (2013). Controlling Helix Formation in the $\mathrm{y}$-Peptide Superfamily: Heterogeneous Foldamers with Urea/Amide and Urea/Carbamate Backbones. Angewandte Chemie - International Edition, 52(15), 4147-4151. doi:10.1002/anie.201209838

Pulka-Ziach, K., \& Sęk, S. (2017). $\alpha$-Helicomimetic foldamers as electron transfer mediators. Nanoscale, 9(39), 14913-14920. doi:10.1039/C7NR05209J

Seebach, D., Beck, A. K., \& Bierbaum, D. J. (2004). The World of $\beta$ - and $\gamma$-Peptides Comprised of Homologated Proteinogenic Amino Acids and Other Components. Chemistry \& Biodiversity, 1(8), 1111-1239. doi:10.1002/cbdv.200490087

Semetey, V., Didierjean, C., Briand, J.-P., Aubry, A., \& Guichard, G. (2002). Self-Assembling Organic Nanotubes from Enantiopure Cyclo-N,N'-Linked Oligoureas: Design, Synthesis, and Crystal Structure. Angewandte Chemie - International Edition, 41(11), 1895-1898. doi:10.1002/15213773(20020603)41:11<1895::AID-ANIE1895>3.0.CO;2-3

Semetey, V., Rognan, D., Hemmerlin, C., Graff, R., Briand, J.-P., Marraud, M., et al. (2002). Stable Helical Secondary Structure in Short-Chain N,N'-Linked Oligoureas Bearing Proteinogenic Side Chains. 
Angewandte Chemie - International Edition, 41(11), 1893-1895. doi:10.1002/15213773(20020603)41:11<1893::AID-ANIE1893>3.0.CO;2-F

Teyssières, E., Corre, J.-P., Antunes, S., Rougeot, C., Dugave, C., Jouvion, G., et al. (2016). Proteolytically Stable Foldamer Mimics of Host-Defense Peptides with Protective Activities in a Murine Model of Bacterial Infection. Journal of Medicinal Chemistry, 59(18), 8221-8232. doi:10.1021/acs.jmedchem.6b00144

Violette, A., Averlant-Petit, M. C., Semetey, V., Hemmerlin, C., Casimir, R., Graff, R., et al. (2005). N,N'Linked Oligoureas as Foldamers: Chain Length Requirements for Helix Formation in Protic Solvent Investigated by Circular Dichroism, NMR Spectroscopy, and Molecular Dynamics. Journal of the American Chemical Society, 127(7), 2156-2164. doi:10.1021/ja044392b

Violette, A., Fournel, S., Lamour, K., Chaloin, O., Frisch, B., Briand, J.-P., et al. (2006). Mimicking Helical Antibacterial Peptides with Nonpeptidic Folding Oligomers. Chemistry \& Biology, 13(5), 531538. doi:10.1016/j.chembiol.2006.03.009

Vojkovsky, T. (1995). Detection of secondary amines on solid phase. Pept Res, 8(4), 236-237.

Wechsel, R., Raftery, J., Cavagnat, D., Guichard, G., \& Clayden, J. (2016). The meso Helix: Symmetry and Symmetry-Breaking in Dynamic Oligourea Foldamers with Reversible Hydrogen-Bond Polarity. Angewandte Chemie - International Edition, 55(33), 9657-9661. doi:10.1002/anie.201604496

Wechsel, R., Žabka, M., Ward, J. W., \& Clayden, J. (2018). Competing Hydrogen-Bond Polarities in a Dynamic Oligourea Foldamer: A Molecular Spring Torsion Balance. Journal of the American Chemical Society, 140(10), 3528-3531. doi:10.1021/jacs.8b00567

Wolfe, S. A., Nekludova, L., \& Pabo, C. O. (2000). DNA recognition by Cys2His2 zinc finger proteins. Annual Review of Biophysics and Biomolecular Structure, 29, 183-212. doi:10.1146/annurev.biophys.29.1.183 
934 Yoo, S. H., Collie, G. W., Mauran, L., \& Guichard, G. (2020). Formation and Modulation of Nanotubular Assemblies of Oligourea Foldamers in Aqueous Conditions using Alcohol Additives. ChemPlusChem, 85(10), 2243-2250. doi:10.1002/cplu.202000373

937 
939 Table 1. Azide type monomers bearing side chain at the ${ }^{\beta} \mathrm{C}$ position prepared according to Figure 4:

940 details of pathway and overall yield.

\begin{tabular}{|c|c|c|c|}
\hline Starting amino acid & Patha & Monomer & Yield $^{b}(\%)$ \\
\hline Boc-Ala-OH & A & $\mathrm{N}_{3}-\mathrm{Ala}^{\mathrm{u}}-\mathrm{OSu}$ & 21 \\
\hline Boc-Val-OH & $\mathbf{A}$ & $\mathrm{N}_{3}-\mathrm{Val}{ }^{\mathrm{u}}-\mathrm{OSu}$ & 25 \\
\hline Boc-Leu-OH & $\mathbf{A}$ & $\mathrm{N}_{3}-\mathrm{Leu}^{\mathrm{u}}-\mathrm{OSu}$ & 28 \\
\hline Boc-Ile-OH & $\mathbf{A}$ & $\mathrm{N}_{3}-I l e^{\mathrm{u}}-\mathrm{OSu}$ & 48 \\
\hline Boc-Phe-OH & A & $\mathrm{N}_{3}-\mathrm{Phe}^{\mathrm{u}}-\mathrm{OSu}$ & 31 \\
\hline Fmoc-Lys(Boc)-OH & B & $\mathrm{N}_{3}-\mathrm{Lys}^{\mathrm{u}}(\mathrm{Boc})-\mathrm{OSu}$ & 26 \\
\hline Fmoc-Glu(Ot'Bu)-OH & B & $\mathrm{N}_{3}-\mathrm{Glu}^{\mathrm{u}}\left(\mathrm{O}^{t} \mathrm{Bu}\right)-\mathrm{OSu}$ & 37 \\
\hline Fmoc-GIn(Trt)-OH & B & $\mathrm{N}_{3}-\mathrm{G} \ln \mathrm{u}(\mathrm{Trt})-\mathrm{OSu}$ & 11 \\
\hline Fmoc-Thr( $\left.\mathrm{O}^{t} \mathrm{Bu}\right)-\mathrm{OH}$ & B & $\mathrm{N}_{3}-\mathrm{Thr}^{\mathrm{u}}\left(\mathrm{O}^{t} \mathrm{Bu}\right)-\mathrm{OSu}$ & 16 \\
\hline Fmoc-Tyr(- $\left.{ }^{t} \mathrm{Bu}\right)-\mathrm{OH}$ & B & $\mathrm{N}_{3}-\mathrm{Tyr}^{\mathrm{u}}\left(\mathrm{O}^{t} \mathrm{Bu}\right)-\mathrm{OSu}$ & 20 \\
\hline Fmoc-Trp(Boc)-OH & B & $\mathrm{N}_{3}-\operatorname{Trp}^{\mathrm{u}}(\mathrm{Boc})-\mathrm{OSu}$ & 17 \\
\hline Fmoc-Arg(Pbf)-OH & B & $\mathrm{N}_{3}-\mathrm{Arg}^{\mathrm{u}}(\mathrm{Pbf})-\mathrm{OSu}$ & 22 \\
\hline
\end{tabular}

${ }^{a}$ See Figure 4. ${ }^{b}$ The yield corresponds to the overall yield.

943 Table 2. Azide type monomers bearing side chain at the ${ }^{\alpha} \mathrm{C}$ position prepared according to Figure 5:

944 details of pathway and overall yield.

\begin{tabular}{|c|c|c|c|}
\hline Starting amino acid & Path ${ }^{a}$ & Monomer & Yield $^{b}(\%)$ \\
\hline Boc-(D)-Ala-OH & A & $\mathrm{N}_{3}-\mathrm{Ala}^{\mathrm{u \alpha}}-\mathrm{OSu}$ & 28 \\
\hline Boc-(L)-Val-OH & $\mathbf{A}$ & $\mathrm{N}_{3}-\mathrm{Val}^{\mathrm{u \alpha}}-\mathrm{OSu}$ & 19 \\
\hline Boc-(L)-Lys(Alloc)-OH & $\mathbf{A}$ & $\mathrm{N}_{3}$-Lys(Alloc) ${ }^{\mathrm{u \alpha}}{ }_{-} \mathrm{OSu}$ & 37 \\
\hline Fmoc-(L)-Trp(Boc)-OH & B & $\mathrm{N}_{3}-\operatorname{Trp}(\mathrm{Boc})^{\mathrm{u} \alpha-O S u}$ & 21 \\
\hline Fmoc-(L)-Arg(Pbf)-OH & B & $\mathrm{N}_{3}-\operatorname{Arg}(\mathrm{Pbf})^{\mathrm{u \alpha}}-\mathrm{OSu}$ & 11 \\
\hline Fmoc-(D)-Lys(Boc)-OH & B & $\mathrm{N}_{3}$-Lys(Boc) ${ }^{\mathrm{u \alpha}}-\mathrm{OSu}$ & 33 \\
\hline
\end{tabular}

